Portland State University

PDXScholar

Civil and Environmental Engineering Master's

Project Reports

Fall 2017

\title{
Evaluating the Performance of Contech's StormFilter with ZPG Media Under the City of Portland's 2016 Stormwater Management Manual Requirements for Manufactured Stormwater Treatment Technologies
}

Mawj T.H. Khammas

Portland State University

Follow this and additional works at: https://pdxscholar.library.pdx.edu/cengin_gradprojects

Part of the Civil and Environmental Engineering Commons

Let us know how access to this document benefits you.

\section{Recommended Citation}

Khammas, Mawj T.H., "Evaluating the Performance of Contech's StormFilter with ZPG Media Under the City of Portland's 2016 Stormwater Management Manual Requirements for Manufactured Stormwater Treatment Technologies" (2017). Civil and Environmental Engineering Master's Project Reports. 38. https://doi.org/10.15760/CCEMP.37

This Project is brought to you for free and open access. It has been accepted for inclusion in Civil and Environmental Engineering Master's Project Reports by an authorized administrator of PDXScholar. Please contact us if we can make this document more accessible: pdxscholar@pdx.edu. 
Evaluating the Performance of Contech's StormFilter with ZPG Media Under the City of Portland's 2016 Stormwater Management Manual Requirements for Manufactured Stormwater Treatment Technologies

\title{
BY
}

Mawj Khammas

A research project report submitted in partial fulfillment of the requirement for the degree of

\author{
MASTER OF SCIENCE \\ IN \\ CIVIL AND ENVIRONMENTAL ENGINEERING
}

Project Advisor:

Dr. William Fish

Portland State University

(C)2017 


\section{ACKNOWLEDGMENTS}

This study benefited from several people and organizations.

- Dr. William Fish provided guidance and advice

- City of Portland / Bureau of Environmental Services (BES)

- The Civil and Environmental Engineering department at Portland State University has supported my work

- My mother and my family 


\begin{abstract}
Stormwater runoff is the water generated from excess rainfall or snowmelt that flows over impervious surfaces such as paved roads, parking lots, and on roofs, it often carries a variety of pollutants that adversely affect water quality in that region. Portland is a well-developed city; the majority of the streets are paved and impervious and will consequently generate a tremendous amount of stormwater this creates the necessity for management to help preserve and mimic natural hydrologic cycle through improving water quality. The StormFilter® with ZPG media, manufactured by $\mathrm{CONTECH}$, is a manufactured stormwater treatment technology(MSTT) in which zeolite, perlite, and granular activated carbon are used. The device has a current Routine Use Level Designation (GULD) for basic treatment from the Washington State Department of Ecology (WA DOE) under the Technology Assessment Protocol-Ecology (TAPE). Storm data from two different sites were used to evaluate the performance of The StormFilter-ZPG with respect to Portland's pollution reduction requirements, as prescribed in the 2016 Stormwater Management Manual (SWMM). The results of the evaluation suggest approving the device for use in the City of Portland at the TAPE-approved flow rate of $1 \mathrm{gpm} / \mathrm{ft}^{2}$.
\end{abstract}




\section{TABLE OF CONTENTS}

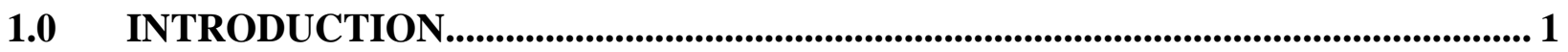

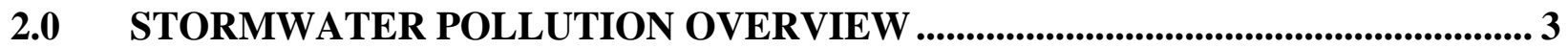

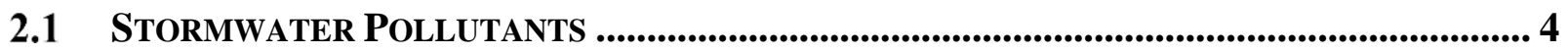

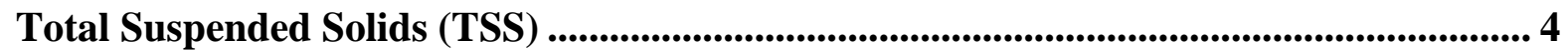

Heavy metals ................................................................................................................................................. 5

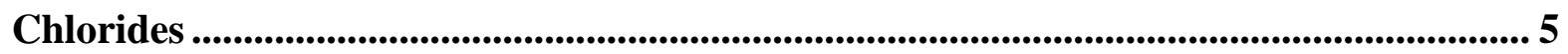

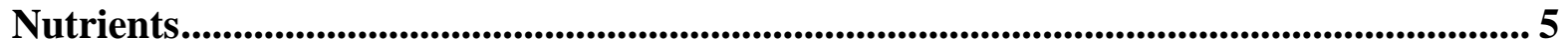

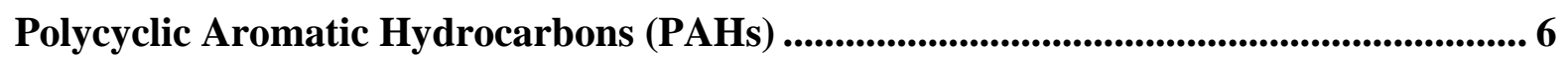

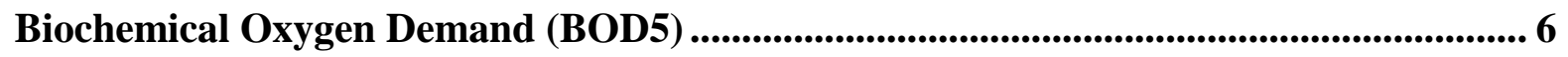

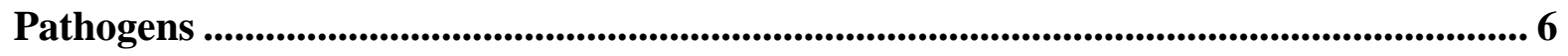

3.0 LAND COVER EFFECT ON GENERATED STORMWATER RUNOFF ............. 10

4.0 SOURCES OF URBAN STORMWATER CONTAMINANTS ............................... 12

Activity Related ................................................................................................................................ 12

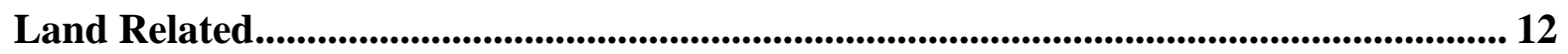

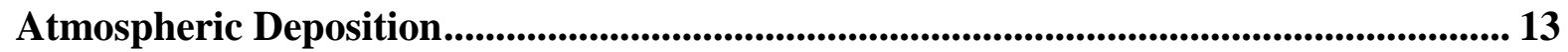

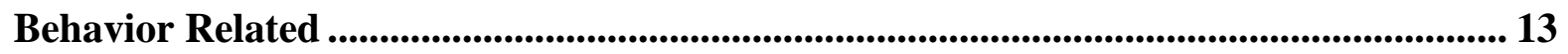

5.0 TECHNOLOGY ASSESSMENT PROTOCOL- ECOLOGY (TAPE) ................... 15

6.0 STORMFILTER-ZPG MEDIA THIRD PARTY EVALUATION PROCESS ........ 18

7.0 STORMFILTER-ZPG MEDIA BACKGROUND .................................................. 20

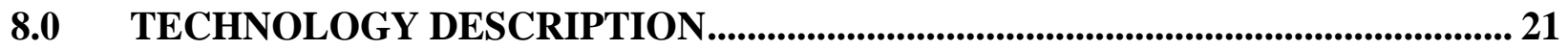

9.0 STORMFILTERS - ZPG MEDIA SIZING PROTOCOL ......................................... 25

10.0 ANTICIPATED LONG-TERM PERFORMANCE AND MAINTENANCE........... 27

11.0 PERFORMANCE TEST SITES DESCRIPTION .................................................. 29

11.1 HERITAGE MARKETPLACE ................................................................................................. 29

11.2 LAKE STEVENS ...................................................................................................... 30

12.0 STORMFILTER - ZPG MEDIA TESTING PERFORMANCE ............................ 32

13.0 REVIEW\& EVALUATION FINDINGS .............................................................. 36

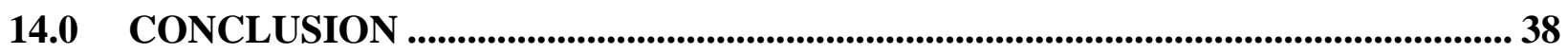




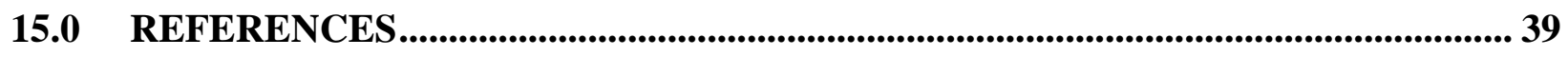

16.0 APPENDIX - MORE ADDITIONAL INFORMATION......................................... 41

16.1 Final REPORT SUbmitTed TO THE City OF PoRTLAND................................................... 41

16.2 TECHNICAL INTERVIEW QUESTIONS..................................................................................5 50 


\section{LIST OF TABLES}

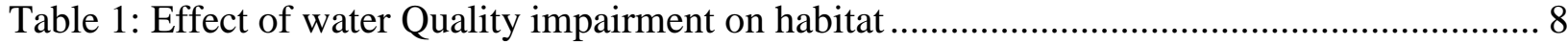

Table 2: Common Urban Stormwater contaminants (EPA. 2015)........................................ 9

Table 3: Median Event Mean concentration of main stormwater pollutants for different Urban

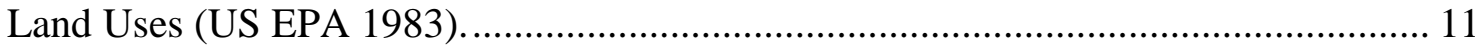

Table 4: TAPE Basic \& Dissolved metals Treatment criteria (Howie. 2011)......................... 16

Table 5: TAPE Phosphorus, oil and pretreatment removal criteria (Howie. 2011)................... 16

Table 6: Comparison in TSS removal between WA (DOE) goals and Portland's requirements. 17

Table 7: CONTECH stormFilter-ZPG media GULD revision history (GULD for CONTECH .2017)

Table 8: Sizing estimates for StormFilter with ZPG media use in City of Portland (CONTECH.

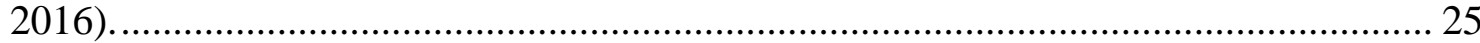

Table 9: Approved GULD rates per cartridge at 1 GPM/FT (CONTECH. 2016). .................... 26

Table 10: Best annual plan for maintenance activities. (CONTECH. 2016) .............................. 27

Table 11: StormFilter maintenance activities (CONTECH. 2016) ........................................ 28

Table 12: Sediment size comparison between the two sites (CONTECH application. 2016)..... 31

Table 13: Qualified storms with aggregate TSS load reduction (CONTECH application. 2016) 33

Table 14: Efficiency Calculations Submitted by Stormwater Management, Inc. as part of the WA DOE TAPE Technical Evaluation Report (TER) for the StormFilter with ZPG (2004a).

Table 15: WA TAPE Goals vs. Portland Requirements vs. TAPE Testing Results for the

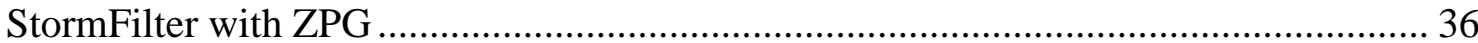




\section{LIST OF FIGURES}

Figure 1: Urban runoff pollution sources and impacts (Tsihrintzis and Hamid, 1997)................ 4

Figure 2:Urban stormwater runoff non -point pollution sources (Petrucci et al. 2014) .............. 14

Figure 3: City of Portland review process and timeline (SWMM. 2016)................................. 19

Figure 4: Cartridges in empty vault .............................................................................. 22

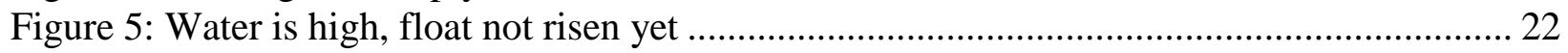

Figure 6: Float is up, water is passing through the underdrain system..................................... 23

Figure 7: Water level has dropped, siphon begins to collapse, air scouring outside of the cartridge

media ....................................................................................................... 23

Figure 8: Sediment falling to the bottom of the cartridge as a reaction to the collapsing siphon. 24

Figure 9: Remaining water drains, imperfect seal at the base of the float ................................ 24

Figure 10: Aerial view of the Heritage Marketplace StormFilter site (CONTECH product evaluation. 2006) .............................................................................................. 30

Figure 11: Aerial view of the Lake Stevens North StormFilter site (CONTECH product

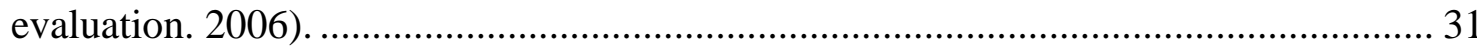

Figure 12: The graph compares the City of Portland's treatment criteria against the performance of the ZPG-filter. Most of the storm effluent concentrations lie below Portland's criteria. 


\subsection{INTRODUCTION}

Stormwater runoff represents a significant non-point source (NPS) of contamination to water bodies. From the onset of a rain event, rain can either infiltrate the soil, evaporate or migrate above different surfaces carrying various contaminants until it reaches receiving water bodies (Tsihrintzis and Hamid, 1997) as shown in Figure 1. Polluted stormwater could adversely affect groundwater as well as surface water and cause degradation in species and fish mortality and most importantly affect human health. A report in early Nineties revealed that in the U.S. stormwater runoff is ranked as the second largest source of pollution in lakes and estuaries and as the third largest source of pollution in rivers (Lee and Jones-Lee, 1994). The Clean Water Act (CWA), created in 1972 set basic regulations for discharging pollutants into surface water bodies in the United States. Under this law, all municipal, industrial and commercial sources that discharge wastewater or stormwater from point source must get a National Pollutant Discharge Elimination System (NPDES) permit to regulate water quality in surface waters. The NPDES stormwater program regulates stormwater discharge to prevent stormwater runoff from washing harmful pollutants into local surface water. The city of Portland has established NPDES under the CWA. The Oregon Department of Environmental Quality issued the first permit for the city in 1995 . The license is formally called the Phase I, National Pollutant Discharge Elimination System (NPDES) Municipal Separate Storm Sewer System (MS4) Discharge Permit. DEQ renewed it for a second term in 2004. Finally, the final third-term permit was issued on January 31, 2011, and expired on January $30^{\text {th. }} 2016$ and has been organizationally extended by the DEQ. The city of Portland has issued a manual, the stormwater management manual (SWMM) that contains all the city's stormwater pollution management strategies. An essential part of the SWMM is Appendix B which has all the rules and requirements needed from any vendor who intends to present their technology to the city of Portland. Each vendor must follow Appendix B to ensure and to prove that their device is capable 
of meeting Portland's requirements and guidelines. Washington State has also developed a stormwater management plan (2008) that is used statewide called Technology Assessment Protocol Ecology (TAPE) (Howie, 2011). In this report, I will discuss my review and evaluation of a manufactured stormwater treatment technology (MMST) made by a company called CONTECH, which has been awarded General Use Level Designation (GULD) under TAPE process from Washington State Department of Ecology (WA DOE). The device is called StormFilter- ZPG media, in which zeolite, perlite, and granular activated carbon are used to trap total suspended solids (TSS) in particular. TSS is given a top priority because it is considered a tracer and evidence for the presence of various other contaminants such as metals, oil and grease, agricultural chemicals, nutrients, hydrocarbons, debris and litter and pathogens. Removal of TSS implies the removal of the associated pollutants. The device was formally approved, in 2002, by the City of Portland, and has been successfully applied in many public and private sites to meet water quality requirements for stormwater, generated runoff. The vendor has reapplied to the City of Portland to get approval for MSTT, under SWMM Appendix B, and my evaluation was done as a part of third party reviewal by Portland State University (PSU). 


\subsection{STORMWATER POLLUTION OVERVIEW}

Stormwater contaminants vary from one place to another depending on many factors such as surface type, land use, and human activities. In addition, different surfaces generate different stormwater content. For instance, surfaces with depressions more easily retain pollutants than a relatively smooth surface. Rough surfaces such as asphalt tend to produce higher contaminant concentrations in the runoff rather than concrete surfaces, because more pollutant will get attached into the asphalt during periods of dry weather hence higher contaminant availability for wash-off (Liu et al. 2014). So, choosing the most effective stormwater treatment design is very crucial in preventing or minimizing stormwater deterioration. Land use and human activities such as construction sites have a significant impact on the amount and variety of pollutants that are added to the runoff. Furthermore, other factors like geographic, meteorological and geologic characteristic of the particular area will affect human activities. (Figure 1) below represents urban runoff contamination sources and different impacts on water bodies and other aspects such as human health, fish mortality and species diversity. 


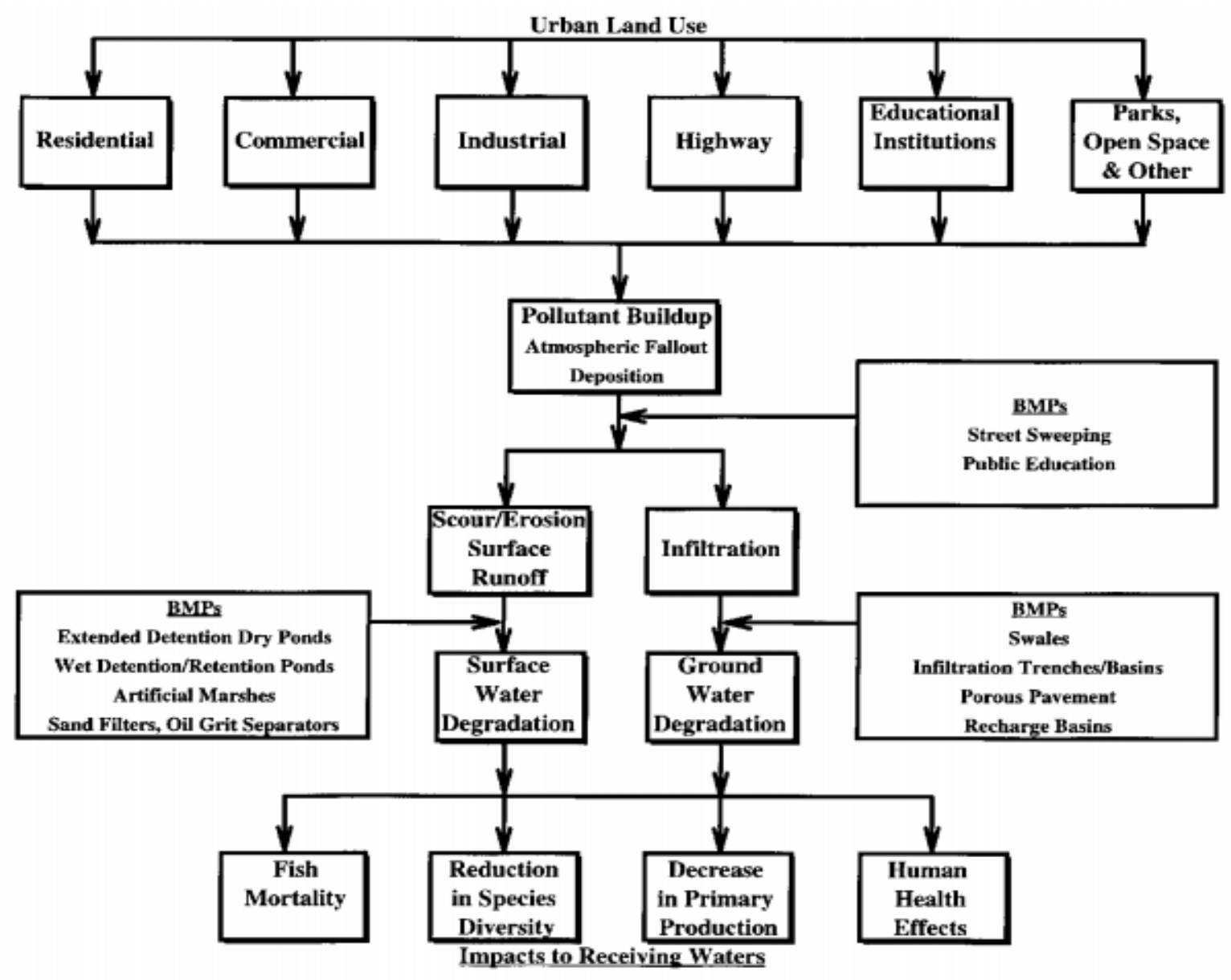

Figure 1: Urban runoff pollution sources and impacts (Tsihrintzis and Hamid, 1997).

\subsection{Stormwater Pollutants}

The following contaminants are typically found in urban stormwater:

\section{Total Suspended Solids (TSS)}

They are considered the main target of removal in any treatment technology. Street dust is the main source of TSS in stormwater and the main cause of its turbidity. Also, more dangerous pollutants tend to adhere to fine TSS particles posing additional contamination problems. 


\section{Heavy metals}

Industrial and commercial land use represent the largest source of heavy metal contribution to the runoff. However, runoff originating from vehicles and traffic related deposits contains the most toxic pollutants like lead deposits from leaded fuel, oxides of lead and zinc from tire wear, copper, and nickel. Certain heavy metals (e.g., copper, lead and zinc) are more soluble in water than others and may cause serious toxic effects at levels exceeding threshold values (Novotny et al. 2008).

\section{Chlorides}

Salt is applied in winter in many parts of the U.S. to prevent snow from adhering to the pavement, hence creating slippery conditions and unsafe driving roads. The primary agent used for deicing is rock salt $(\mathrm{NaCl})$. The annual usage of $\mathrm{NaCl}$ for this purpose has been increasing dramatically from 163,000 tons in 1940 to 23 million ton in 2005 according to United States Geological Survey (USGS). Salts can either wash off to receiving waters through runoff or percolate to groundwater.

\section{Nutrients}

Urban stormwater runoff may carry elevated concentrations of phosphorus $(\mathrm{P})$, and nitrogen $(\mathrm{N})$, compounds that can leach in to receiving water bodies and cause eutrophication. The main source of these nutrients is agricultural runoff where soil amendments and fertilizers are used. In urban areas, the main source of nutrients is industrial discharge, detergents, animal waste and fertilizers (Zahraa.2013). Most of the stormwater runoff $\mathrm{P}$ load is particulate, while available algal $\mathrm{P}$ comes from mainly soluble P and only $20 \%$ of the particulate P. Therefore, about $80 \%$ of the stormwater particulate P doesn't support algal growth (Lee and Lee. 2005). 


\section{Polycyclic Aromatic Hydrocarbons (PAHs)}

Polycyclic aromatic hydrocarbons a ubiquitous organic compound released by both natural combustion processes and anthropogenic activities. Many PAHs have been identified as known or suspected human carcinogens. The United States Environmental Protection Agency (US EPA) lists PAHs as one of the compounds most likely to be associated with Tier 1 impacted aquatic sediments, where "adverse effects on aquatic life or human health are probable" (Alison et al. 2010). The main human source of PAHs is truck and automobile exhaust, emitted into the atmosphere. These PAHs scrubbed by rainfall and constitute vital source of runoff contamination and hydrocarbon build-up and accumulation (Tsihrintzis and Hamid. 1997). It is estimated that 70\% of the total PAHs found in receiving waters are related to urbanization and traffic density represented in highway runoff.

\section{Biochemical Oxygen Demand (BOD5)}

$\mathrm{BOD}_{5}$ is a water pollutant as well as a useful indicator of other contamination. The conventional sources of $\mathrm{BOD}_{5}$ is usually from vegetation, litter and garbage and animal waste. Elevated BOD will induce higher oxygen demand and can drive water bodies to anoxic or anaerobic conditions due to oxygen depletion. Under anaerobic conditions, metals and nutrients are released from sediments faster than they should be. A typical $\mathrm{BOD}_{5}$ concentration of $12 \mathrm{mg} / \mathrm{L}$ was observed in stormwater discharge from nationwide urban runoff program NURP, EPA.

\section{Pathogens}

Pathogens include viruses, bacteria and protozoa. In general, coliform bacteria are used as an indicator for the presence of other pathogens in water. Some studies have shown elevated levels 
of coliform bacteria in stormwater, especially in dry weather flow. The most important source of pathogens is septic systems and illicit connections from toilets to storm sewer pipes. Determinations regarding pathogen impairment are based on the comparison between fecal indicator bacteria (FIB) such as Escherichia coli (E. coli), enterococci or fecal coliform concentrations to similar water body standards and classifications (Urban Water Resources Research Council. 2014).

All the mentioned stormwater contaminants and others cause numerous complications affecting water quality, water quantity, public health, aesthetic appearance of urban waterways and aquatic habitat and biological resources. The most adverse impact of urban stormwater on receiving waters is the alteration of species distribution, degradation of native species with the growing of pollutant tolerant and less sensitive species. (Table 1), emphasize water quality parameters that have a significant effect on habitat (EPA.2014) 
Table 1: Effect of water Quality impairment on habitat

\begin{tabular}{|l|l|}
\hline $\begin{array}{l}\text { Water Quality } \\
\text { Parameter }\end{array}$ & Habitat Effect \\
\hline Bacteria & Contamination \\
\hline Heavy metals & Alteration of species distribution \\
\hline Toxic organics & Alteration of species distribution \\
\hline Nutrients & Eutrophication, algal blooms \\
\hline Sediment & Decreased spawning areas \\
\hline BOD & Reduced dissolved oxygen levels \\
\hline Temperature & Reduced dissolved oxygen levels \\
\hline pH & Alteration of species distribution \\
\hline
\end{tabular}

Contaminants commonly found in urban stormwater runoff and their source are summarized in (Table 2). 
Table 2: Common Urban Stormwater contaminants (EPA. 2015).

\begin{tabular}{|l|l|}
\hline \multicolumn{1}{|c|}{ Contaminant } & \multicolumn{1}{c|}{ Contaminant Sources } \\
\hline Sediment and Floatables & $\begin{array}{l}\text { Streets, lawns, driveways, roads, construction } \\
\text { activities, atmospheric deposition, drainage } \\
\text { channel erosion }\end{array}$ \\
\hline Pesticides and Herbicides & $\begin{array}{l}\text { Residential lawns and gardens, roadsides, } \\
\text { utility right-of-ways, commercial and } \\
\text { industrial landscaped areas, soil wash-off }\end{array}$ \\
\hline Organic Materials & $\begin{array}{l}\text { Residential lawns and gardens, commercial } \\
\text { landscaping, animal wastes }\end{array}$ \\
\hline Metals & $\begin{array}{l}\text { Automobiles, bridges, atmospheric deposition, } \\
\text { industrial areas, soil erosion, corroding metal } \\
\text { surfaces, combustion processes }\end{array}$ \\
\hline Oil and Grease/ & $\begin{array}{l}\text { Roads, driveways, parking lots, vehicle } \\
\text { maintenance areas, gas stations, illicit } \\
\text { dumping to storm drains }\end{array}$ \\
\hline Bacteria and Viruses & $\begin{array}{l}\text { Lawns, roads, leaky sanitary sewer lines, } \\
\text { sanitary sewer cross-connections, animal } \\
\text { waste, septic systems }\end{array}$ \\
\hline Nitrogen and Phosphorus & $\begin{array}{l}\text { Lawn fertilizers, atmospheric deposition, } \\
\text { automobile exhaust, soil erosion, animal } \\
\text { waste, detergents }\end{array}$ \\
\hline
\end{tabular}




\subsection{LAND COVER EFFECT ON GENERATED STORMWATER RUNOFF}

The pollutants mentioned found in general, but different surfaces will yield different ranges of contaminants. Also, runoff generated from urban and non-urban sites is entirely different. Since the inception of water quality act in 1965, many intensive types of research and studies have been done in the urban stormwater field to characterize its nature to apply the most suitable Best Management Practices (BMPs). EPA's Nationwide Urban Runoff Program (NURP); did a comprehensive study between 1978 and 1983 of urban runoff characteristics and the effect of land use on the type of the runoff. Sampling was conducted for 28 NURP projects which included 81 specific sites and more than 2,300 different storm events. (Table 3), lists the median event mean concentration (EMCs) for ten general NURP pollutants for various land use categories. It shows that, for urban sites, pollutant concentrations do not significantly vary with land use categories. However, a significant difference is found between urban and non-urban areas (US EPA 1983). 
Table 3: Median Event Mean concentration of main stormwater pollutants for different Urban Land Uses (US EPA 1983).

\begin{tabular}{|l|c|c|c|c|c|c|c|c|c|}
\hline \multirow{2}{*}{ Pollutant } & \multirow{2}{*}{ Units } & \multicolumn{2}{c|}{ Residential } & \multicolumn{2}{c|}{ Mixed } & \multicolumn{2}{c|}{ Commercial } & \multicolumn{3}{c|}{$\begin{array}{c}\text { Open/ } \\
\text { Non-Urban }\end{array}$} \\
\cline { 3 - 10 } & & Median & COV & Median & COV & Median & COV & Median & COV \\
\hline BOD & $\mathrm{mg} / 1$ & 10 & 0.41 & 7.8 & 0.52 & 9.3 & 0.31 & -- & -- \\
\hline COD & $\mathrm{mg} / 1$ & 73 & 0.55 & 65 & 0.58 & 57 & 0.39 & 40 & 0.78 \\
\hline TSS & $\mathrm{mg} / 1$ & 101 & 0.96 & 67 & 1.14 & 69 & 0.85 & 70 & 2.92 \\
\hline Total Lead & $\mu \mathrm{g} / 1$ & 144 & 0.75 & 114 & 1.35 & 104 & 0.68 & 30 & 1.52 \\
\hline Total Copper & $\mu \mathrm{g} / 1$ & 33 & 0.99 & 27 & 1.32 & 29 & 0.81 & -- & -- \\
\hline Total Zinc & $\mu \mathrm{g} / 1$ & 135 & 0.84 & 154 & 0.78 & 226 & 1.07 & 195 & 0.66 \\
\hline $\begin{array}{l}\text { Total Kjeldahl } \\
\text { Nitrogen }\end{array}$ & $\mu \mathrm{g} / 1$ & 1900 & 0.73 & 1288 & 0.50 & 1179 & 0.43 & 965 & 1.00 \\
\hline $\begin{array}{l}\text { Nitrate }+ \\
\text { Nitrite }\end{array}$ & $\mu \mathrm{g} / 1$ & 736 & 0.83 & 558 & 0.67 & 572 & 0.48 & 543 & 0.91 \\
\hline $\begin{array}{l}\text { Total } \\
\text { Phosphorus }\end{array}$ & $\mu \mathrm{g} / 1$ & 383 & 0.69 & 263 & 0.75 & 201 & 0.67 & 121 & 1.66 \\
\hline $\begin{array}{l}\text { Soluble } \\
\text { Phosphorus }\end{array}$ & $\mu \mathrm{g} / 1$ & 143 & 0.46 & 56 & 0.75 & 80 & 0.71 & 26 & 2.11 \\
\hline
\end{tabular}

COV: Coefficient of variation 


\subsection{SOURCES OF URBAN STORMWATER CONTAMINANTS}

In general, nonpoint sources of urban stormwater pollutants can be divided into activity- related, land- related, behavior- related and atmospheric deposition (Petrucci et al. 2014). Knowing the source of stormwater is a useful way to predict and to expect which pollutants could be present.

\section{Activity Related}

The main human activates that generate a tremendous amount of pollutants are road transport emissions, railway transport emissions and domestic heating (Petrucci et al. 2014). Coal and wood are considered the more pollution-causing type of fuels, although their use is limited in the urban area. Specific studies on particular catchment have shown that human activities are the cause of copper $(\mathrm{Cu})$ and polycyclic aromatic hydrocarbons (PAHs) contamination, through brake pad wear and tire wear respectively (Petrucci et al. 2014)

\section{Land Related}

Building roofs imperviousness and infrastructure generate runoff. They can add a substantial number of contaminants to stormwater depending on the material of manufacture. For instance, infrastructure materials such as train and tramway catenaries, guardrails, urban lights road panels and markings are considered significant metal sources, a result of a particular study has shown that land cover materials are responsible for lead (Pb) and zinc ( $\mathrm{Zn})$ Pollution (Petrucci et al. 2014) 


\section{Atmospheric Deposition}

Fraction of the land-emitted pollutants is transferred to the atmosphere, pollutants from various sources are mixed, finally, some atmospheric pollutants can re-enter the land and pass through urban runoff either through wet deposition, dry deposition or a combination of a set of processes.

\section{Behavior Related}

The emission of some pollutants is strongly related to individual human or institutional behavioral activities, such as the usage of pesticides, biocides, fertilizers or other chemicals. Assessing and controlling these emissions is very complicated, so strong knowledge of local traditions, regulations, and practice, social and economic conditions must be determined (Petrucci et al. 2014).

(Figure 2) below summarizes the Non-point contamination sources. 


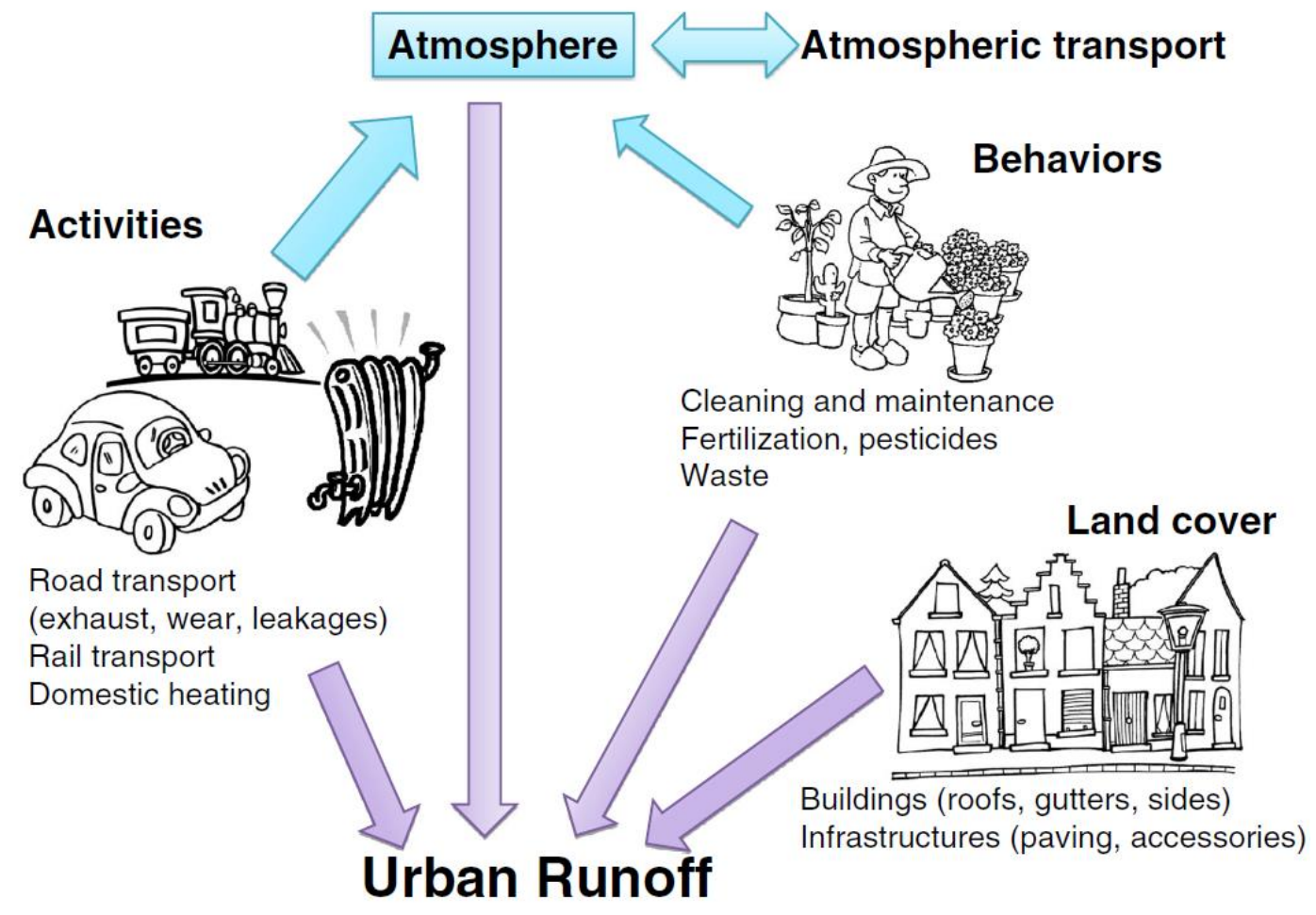

Figure 2:Urban stormwater runoff non -point pollution sources (Petrucci et al. 2014) 


\subsection{TECHNOLOGY ASSESSMENT PROTOCOL- ECOLOGY (TAPE)}

TAPE is a Washington State protocol that provides certification for emerging stormwater treatment technologies, corresponding to one or more of the five performance goals (Table 4), (Table 5) and the design criteria and performance goals for stormwater treatment facilities. Ecology evaluates the technology to assign the use level designation that determines the number of installations that maybe installed in Washington and the monitoring requirement needed for them to obtain additional performance data. There are two categories of use level designation. Ecology will place any technology under one of two application levels.

- Pilot use level designation (PULD), when there are sufficient lab data indicates that the technology's performance meets TAPE.

- Conditional use level designation (CULD), when there is a field data in addition to lab data that indicates the technologies' performance will more likely meet TAPE goals.

The PULD and CULD allow the device to be installed and operated in the state of Washington to gather more performance and monitoring data as a preparation for the final general use level designation (GULD) certification (Howie. 2011). TAPE certification is given when the new technology has successfully met TAPE performance goals when properly installed, operated and maintained. Several states and local jurisdiction use TAPE certification to determine whether the new technology can or cannot be installed within their jurisdiction. 
Table 4: TAPE Basic \& Dissolved metals Treatment criteria (Howie. 2011).

\begin{tabular}{|c|c|c|}
\hline Performance Goal & Influent Range & Criteria ${ }^{a}$ \\
\hline \multirow[t]{3}{*}{ Basic Treatment } & $20-100 \mathrm{mg} / \mathrm{L}$ TSS & Effluent goal $\leq 20 \mathrm{mg} / \mathrm{L}$ TSS \\
\hline & $100-200 \mathrm{mg} / \mathrm{L}$ TSS & $\geq 80 \%$ TSS removal \\
\hline & $>200 \mathrm{mg} / \mathrm{L} \mathrm{TSS}$ & $>80 \%$ TSS removal \\
\hline \multirow[t]{2}{*}{$\begin{array}{l}\text { Dissolved Metals } \\
\text { Treatment }\end{array}$} & $\begin{array}{l}\text { Dissolved copper } \\
0.005-0.02 \mathrm{mg} / \mathrm{L}\end{array}$ & $\begin{array}{l}\text { Must meet basic treatment goal and } \\
\text { better than basic treatment currently } \\
\text { defined as }>30 \% \text { dissolved copper } \\
\text { removal }\end{array}$ \\
\hline & $\begin{array}{l}\text { Dissolved zinc } \\
0.02-0.3 \mathrm{mg} / \mathrm{L}\end{array}$ & $\begin{array}{l}\text { Must meet basic treatment goal and } \\
\text { better than basic treatment currently } \\
\text { defined as }>60 \% \text { dissolved zinc } \\
\text { removal }\end{array}$ \\
\hline
\end{tabular}

Table 5: TAPE Phosphorus, oil and pretreatment removal criteria (Howie. 2011).

\begin{tabular}{|c|c|c|}
\hline Performance Goal & Influent Range & Criteria $^{\mathbf{a}}$ \\
\hline $\begin{array}{l}\text { Phosphorus } \\
\text { Treatment }\end{array}$ & $\begin{array}{l}\text { Total phosphorus (TP) } \\
0.1 \text { to } 0.5 \mathrm{mg} / \mathrm{L}\end{array}$ & $\begin{array}{l}\text { Must meet basic treatment goal and } \\
\text { exhibit } \geq 50 \% \text { TP removal }\end{array}$ \\
\hline Oil Treatment & $\begin{array}{l}\text { Total petroleum } \\
\text { hydrocarbon }(\mathrm{TPH})>10 \\
\mathrm{mg} / \mathrm{L}\end{array}$ & $\begin{array}{l}\text { 1) No ongoing or recurring visible } \\
\text { sheen in effluent } \\
\text { 2) Daily average effluent TPH } \\
\text { concentration }<10 \mathrm{mg} / \mathrm{L} \\
\text { 3) Maximum effluent } \mathrm{TPH} \\
\text { concentration of } 15 \mathrm{mg} / \mathrm{L} \text { for a } \\
\text { discrete (grab) sample }\end{array}$ \\
\hline \multirow[t]{2}{*}{ Pretreatment ${ }^{b}$} & $50-100 \mathrm{mg} / \mathrm{L}$ TSS & $\leq 50 \mathrm{mg} / \mathrm{L}$ TSS \\
\hline & $\geq 200 \mathrm{mg} / \mathrm{L}$ TSS & $\geq 50 \%$ TSS removal \\
\hline \multicolumn{3}{|c|}{$\begin{array}{l}\text { a. See TAPE Technical Guidance Manual for further details. } \\
\text { b. Pretreatment technologies generally apply to (1) project sites using infiltration treatment } \\
\text { and (2) treatment systems where pretreatment is needed to ensure and extend } \\
\text { performance of the downstream basic or dissolved metals treatment facilities. } \\
\mathrm{mg} / \mathrm{L} \text { - milligrams per liter }\end{array}$} \\
\hline
\end{tabular}


StormFilter-ZPG media, which is evaluated in this paper, has been awarded GULD for basic treatment, removal of TSS. However, a sufficient knowledge of Portland's TSS removal requirements is still essential for the City of Portland to assess the usage of any technology in the area. Because of the difference in Portland and Washington requirements, it is vital to investigate any technology before implementing and using in Portland regardless of the similarities between the two cities regarding climate and geographic land cover (Zahraa. 2013). Table 6, illustrates the differences in TSS removal in both, and as can be seen, Washington Department of Ecology WA (DOE) has stricter rules. In general, if the device was accepted in the state of Washington under TAPE process, and was awarded GULD, it will probably be accepted in Portland after review and third-party evaluation from Portland State University. The assessment process involves many stages that will be covered in the following pages.

Table 6: Comparison in TSS removal between WA (DOE) goals and Portland's requirements.

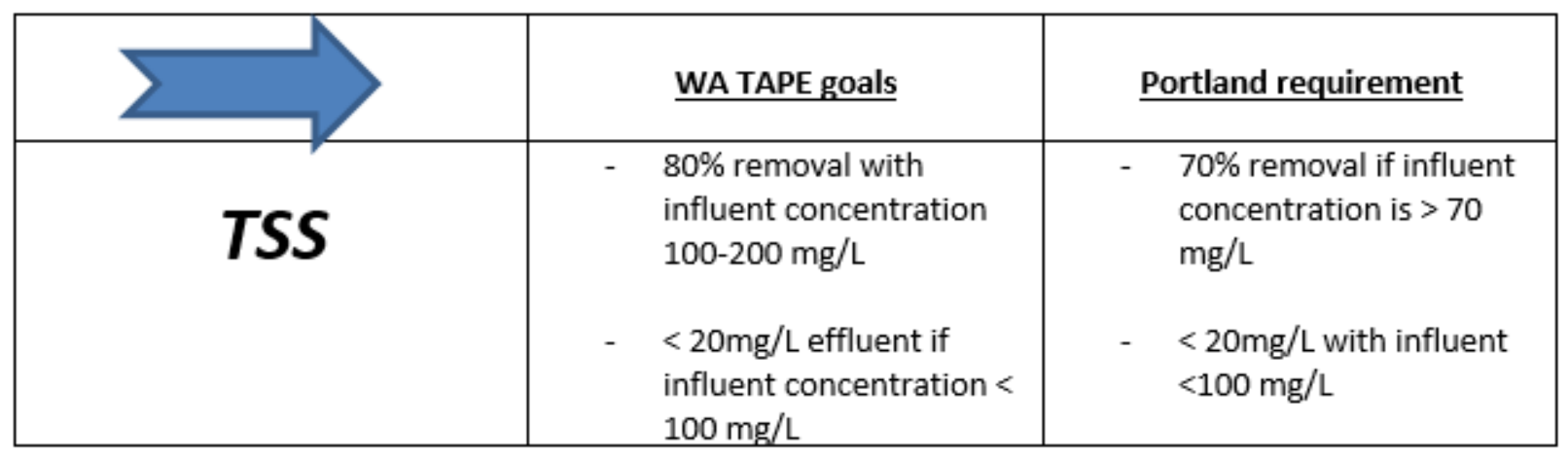




\subsection{STORMFILTER-ZPG MEDIA THIRD PARTY EVALUATION PROCESS}

The assessment process involved:

1. The vendor's (CONTECH) public presentation, in which they discussed their technology, long time performance and maintenance.

2. Technical interview that is not open to the public and consists of answering questions that were submitted to them two weeks prior, based on a preliminary review of the submitted materials. The questions were prepared by myself after being revised from Dr. William Fish, both representing the third party, and from other team members from the city representing the review committee.

3. A deep study of their material, TAPE and GULD findings of fact, technology evaluation engineering report (TEER) and Portland's storm water management manual SWMM, especially chapter 2 , section 2.4.8., all were used to construct a third-party evaluation report. The report analyzed all the qualified storm criteria and the average pollutant reduction and loading rate. Eventually, a recommendation was made based on the review process, and the report submitted to the city for corrections and editing before publishing the final report. Both the final draft and the technical presentation questions are in the Appendix for reference.

(Figure 3) below, summarizes the MSTT reviewing process and timeline for all three parties: PSU, vendor and the City of Portland represented by the BES. 


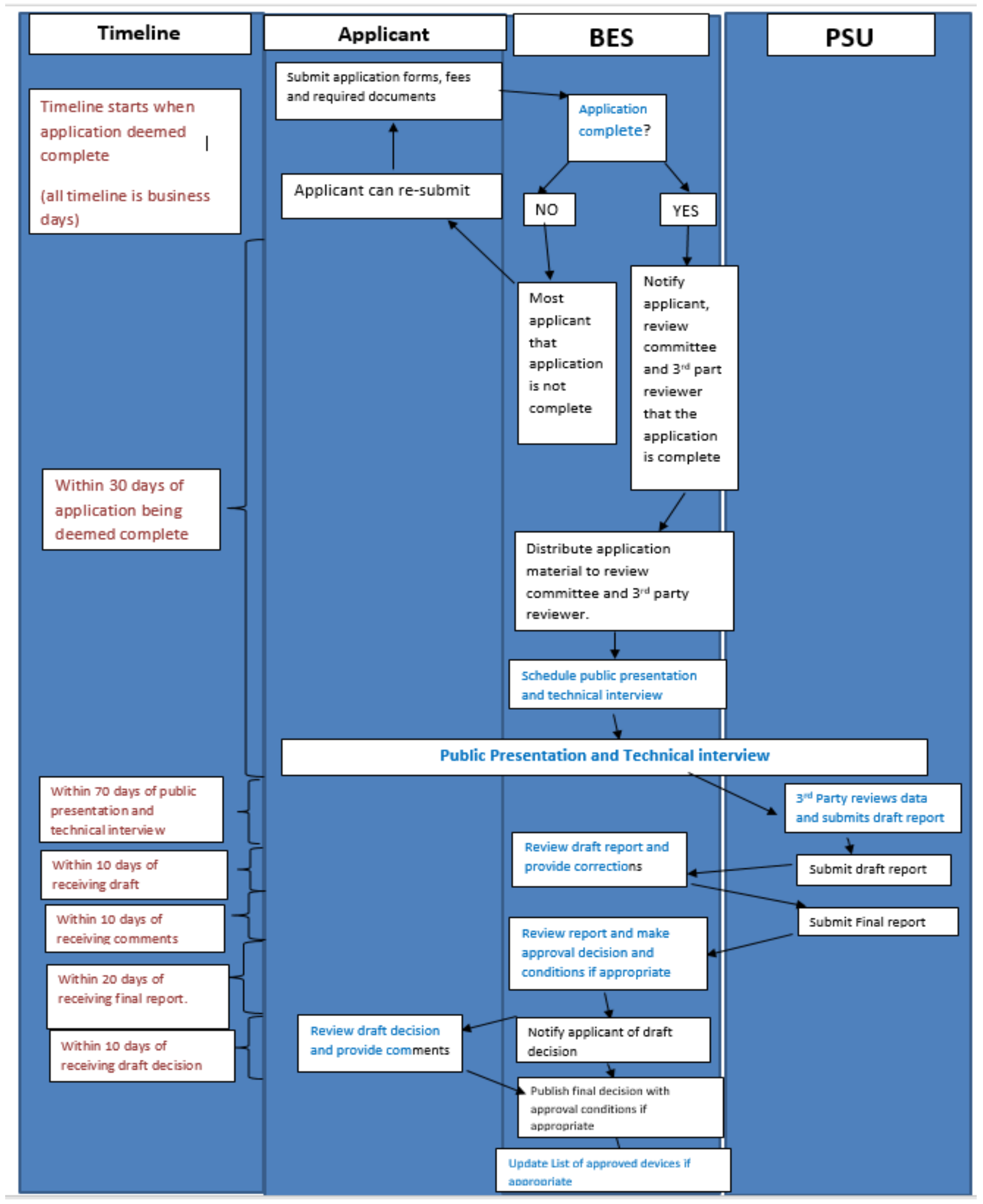

Figure 3: City of Portland review process and timeline (SWMM. 2016) 


\subsection{STORMFILTER-ZPG MEDIA BACKGROUND}

The device was formally approved in 2002 by the City of Portland and has been successfully applied in many public and private sites to meet water quality requirements for stormwater runoff. In addition, it was awarded GULD certification for Basic Treatment by the Washington Department of Ecology in January 2005 under the TAPE process. Since then, GULD was expanded to include other changes and modifications due to Ecology's sizing requirements ( ftp://ftp02.portlandoregon.gov/BES/SWMM PSU COP). The most recent update of GULD certification was in April 2017 (GULD for CONTECH .2017) (Table 7). According to 2014 City of Portland Stormwater Management Manual (SWMM), all approved technologies have a threeyear expiration date, after which they must resubmit their information to the city for re-approval. In January 2017 Contech Stormfilter resubmitted their application to the city at the previously approved water quality and flow rates of 2005.

Table 7: CONTECH stormFilter-ZPG media GULD revision history (GULD for CONTECH .2017).

\begin{tabular}{|l|l|}
\hline Date & Revision \\
\hline Jan 2005 & Original Use Level Designation \\
\hline Dec 2007 & Revision \\
\hline May 2012 & Maintenance requirements updated \\
\hline November 2012 & Design Storm and Maintenance requirements updated \\
\hline January 2013 & Updated format to match Ecology standard format \\
\hline September 2014 & Added Peak Diversion StormFilter Alternate Configuration \\
\hline November 2016 & Revised Contech contact information \\
\hline April 2017 & $\begin{array}{l}\text { Revised sizing language to note sizing based on Off-line } \\
\text { calculations }\end{array}$ \\
\hline
\end{tabular}




\subsection{TECHNOLOGY DESCRIPTION}

The StormFilter is an inline, media-filled cartridge system that removes pollutants from stormwater runoff. The system is contained in a precast concrete vault that can be designed in multiple configurations and sizes. Each filter is designed to treat a specific flow rate, which can be controlled through a calibrated reducer disk at the base of the cartridge. StormFilters may include an internal bypass in case flow rates exceed the capacity of the cartridges. In case the site generates a flow that exceeds the internal bypass capacity, a peak diversion configuration must be used, which integrates the diversion weir with the filter bay into the same vault structure.

The StormFilter ${ }^{\circledR}$ with ZPG, which is the subject of this review, is expressly designed to remove Total Suspended Solids (TSS) from stormwater runoff. The media is comprised of zeolite, perlite, and granular activated carbon (GAC). The outer layer is $100 \%$ perlite; the inner layer is a mixture of $90 \%$ Zeolite and 10\% GAC. Many physical processes contribute to the treatment of the stormwater: filtration, by trapping the suspended particles in the ZPG media, ion exchange, adsorption and precipitation for larger particles. Cartridges are housed in a vault and receive stormwater horizontally through the inlet pipe. Stormwater passes through the filtration media (ZPG) and begins filling the cartridge's center tube. When water reaches the top of the cartridge, the float valve opens, and filtered water can drain at the design flow rate. Treated water is then released out of the system through the under-drain manifold. When the water level outside the cartridge moves toward the base of the hood, air will rush through the scrubbing regulators, releasing the water column and breaking the siphon as shown in Figure 4 through Figure 9 ).The chaotic bubbling movement disturbs the filter media surface, triggering trapped sediment to sink to the vault floor. This surface cleaning mechanism helps restore the permeability of the filter surface between storm events. 


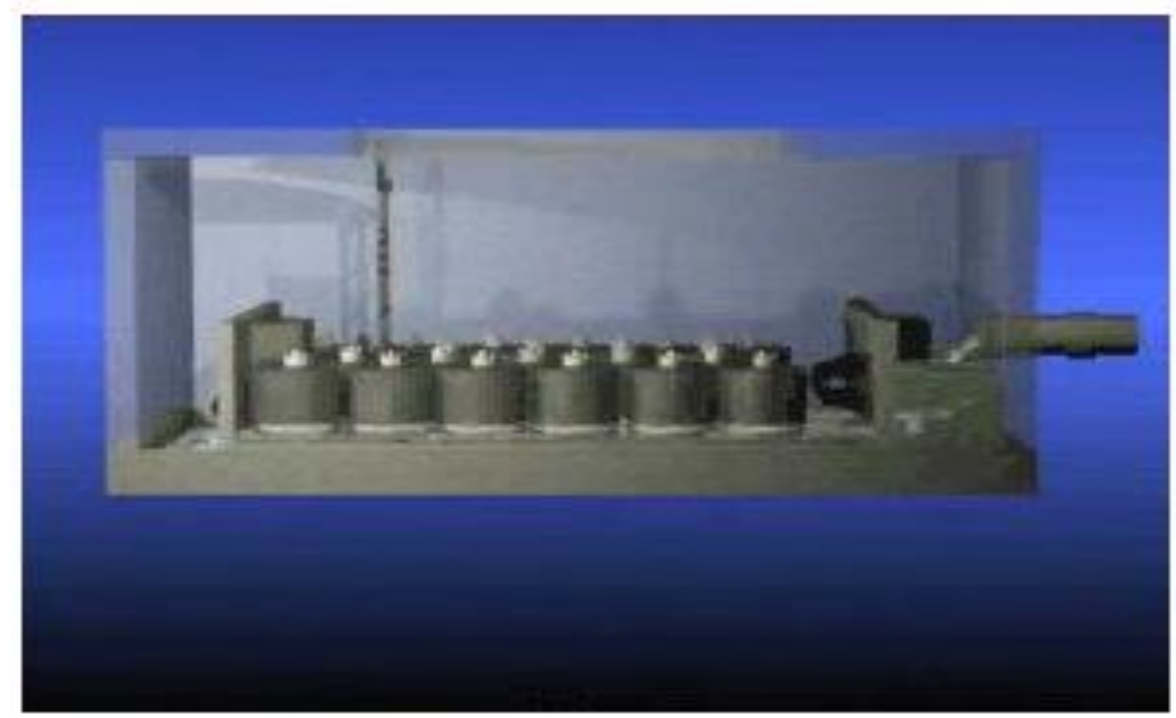

Figure 4: Cartridges in empty vault

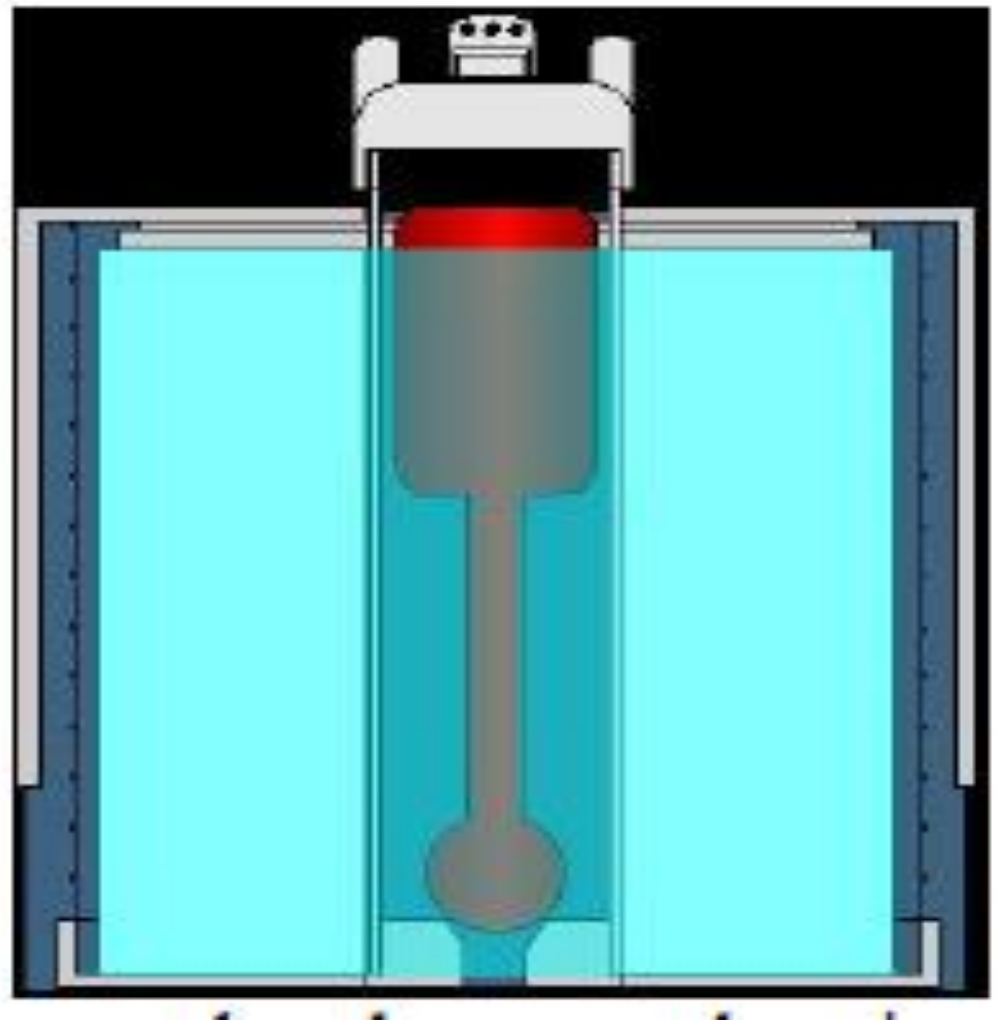

Figure 5: Water is high, float not risen yet 


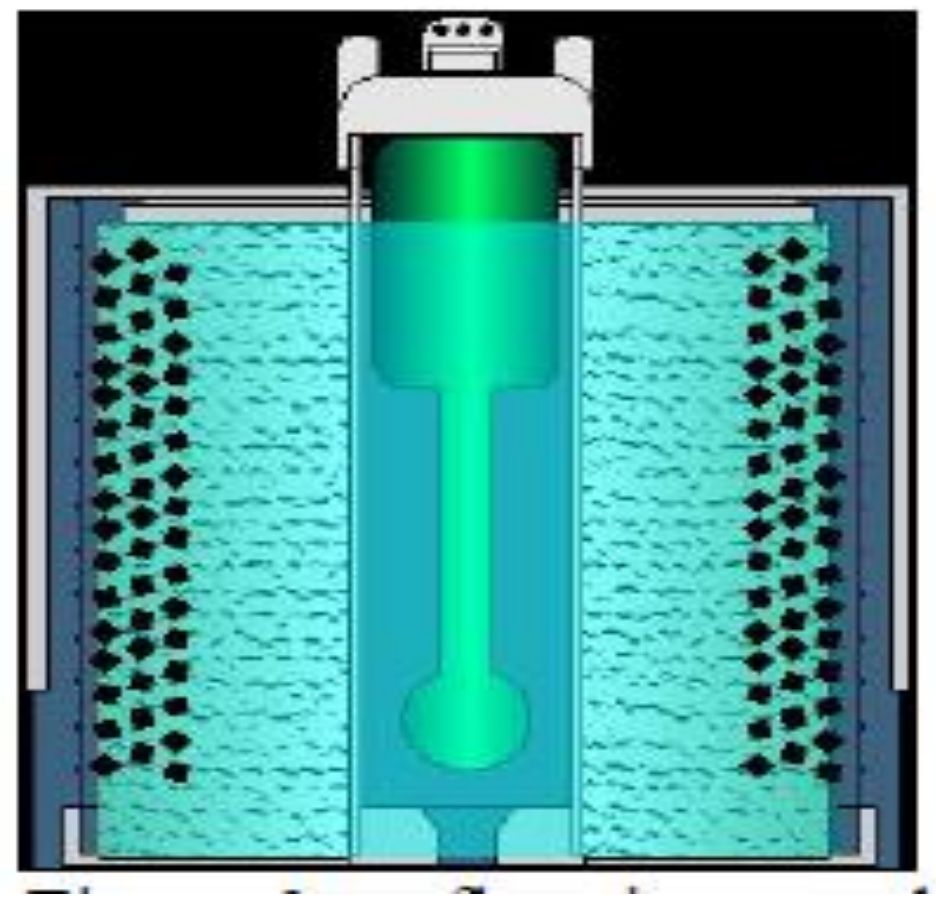

Figure 6: Float is up, water is passing through the underdrain system

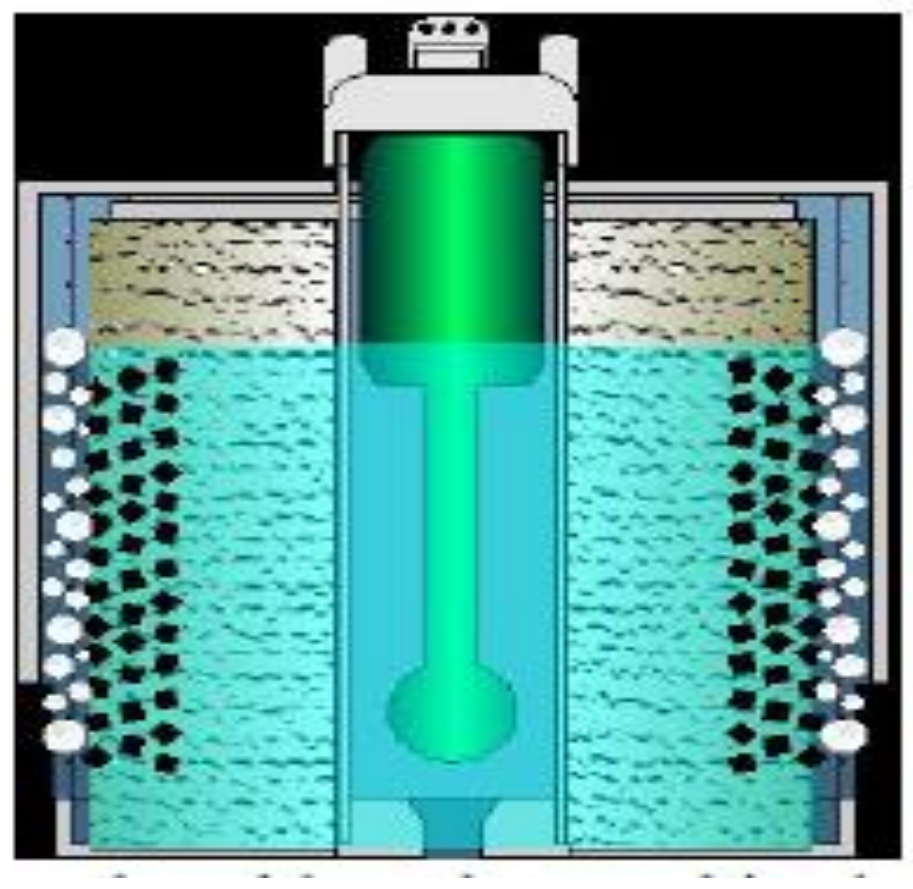

Figure 7: Water level has dropped, siphon begins to collapse, air scouring outside of the cartridge media 


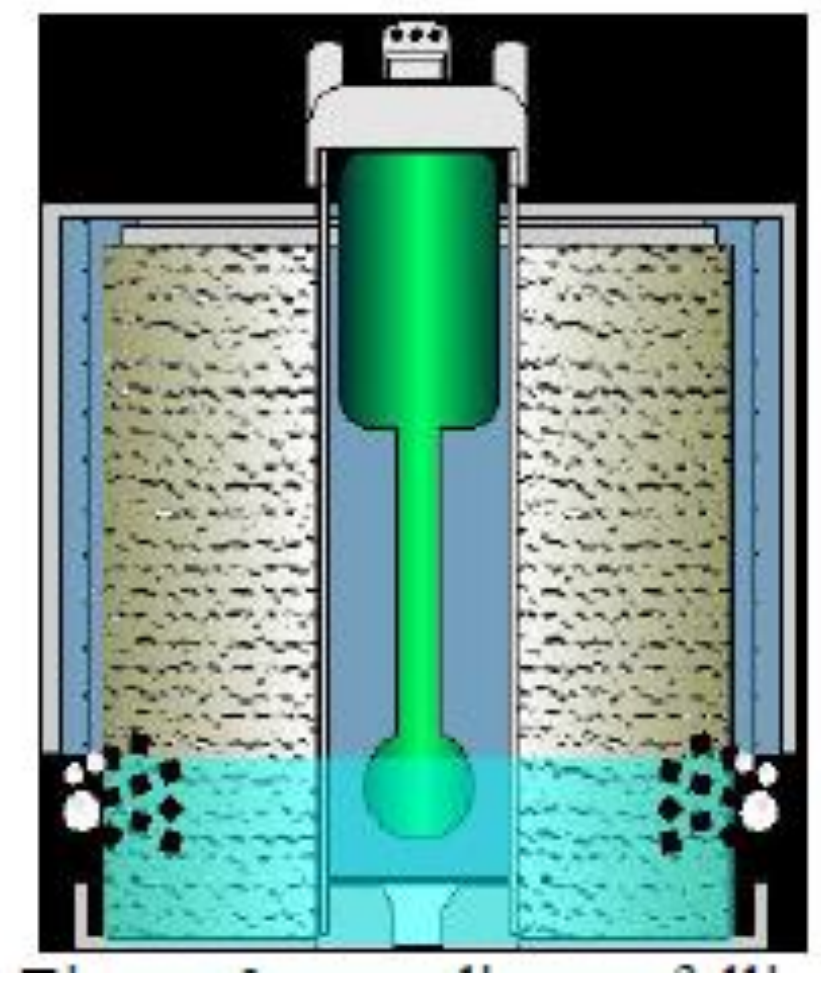

Figure 8: Sediment falling to the bottom of the cartridge as a reaction to the collapsing siphon

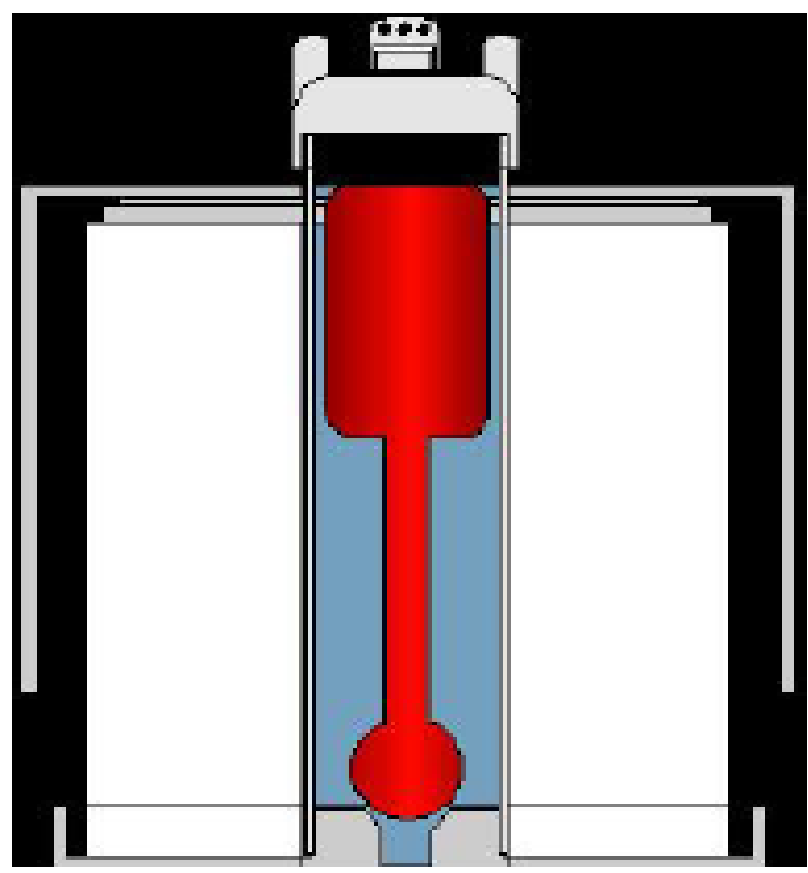

Figure 9: Remaining water drains, imperfect seal at the base of the float 


\subsection{STORMFILTERS - ZPG MEDIA SIZING PROTOCOL}

CONTECH did not provide a specific sizing table for the City of Portland. However, during the technical interview with the City of Portland, the applicant provided the following a sizing table estimates (Table 8). During the performance approach, the Santa Barbara Urban Hydrograph method (SBUH) was used to determine the flow rate at which almost $90 \%$ of the average annual stormwater runoff is treated. GULD was originally approved and awarded for an 18 " cartridge for both single- event runoff modeling with $2 \mathrm{gpm} / \mathrm{sf}$ and continuous simulation runoff modeling with $1 \mathrm{gpm} / \mathrm{sf}$. However, due to the large incompatibility in site's runoff values that showed a dramatic peak in the flow rate resulted from SBUH modeling compared with flow generated by the off-line15-min flow rate generated by Western Washington Hydrology Model (WWHM), Ecology amended the GULD to require more cartridges height and eliminated the single event modeling in favor of the continuous, primarily using WWHM. (Table 9) below summarizes all the approved cartridge flow rate and height.

CONTECH is seeking to maintain approval for basic treatment for $2 \mathrm{gpm} / \mathrm{sf}$ although Ecology is no longer approving that flow with single- event modeling. The applicant provided an example of the PDX Airport showing the equivalency between the two methods and stated explicitly during the interview that the two systems will have similar TSS removal independent of particle size.

Table 8: Sizing estimates for StormFilter with ZPG media use in City of Portland (CONTECH. 2016).

\begin{tabular}{|l|c|c|c|}
\hline \multicolumn{2}{|c|}{ Cartridge Flow Rates } & \multicolumn{2}{c|}{ Flow Rate (gpm/cartridge) } \\
\cline { 3 - 4 } & $12 "$ & $\mathbf{2 ~ g p m} / \mathrm{ft}^{2}$ & $\mathbf{1 ~ g p m} / \mathrm{ft}^{2}$ \\
\hline \multirow{3}{*}{ StormFilter } & $12^{\prime \prime}$ & 10 & 5 \\
\cline { 3 - 4 } & $27^{\prime \prime}$ & 15 & 7.5 \\
\hline
\end{tabular}


Table 9: Approved GULD rates per cartridge at 1 GPM/FT (CONTECH. 2016).

\begin{tabular}{|l|c|c|c|}
\hline Effective Cartridge Height (inches) & 12 & 18 & 27 \\
\hline Cartridge Flow Rate (gpm/cartridge) & 5 & 7.5 & 11.3 \\
\hline
\end{tabular}




\subsection{ANTICIPATED LONG-TERM PERFORMANCE AND MAINTENANCE}

StormFilter-ZPG media system is designed to trap TSS and other particles through its porous media, so as particles fill the filter's openings, the flow decreases, eventually requiring a cartridge replacement. In general, annual replacement is required for most sites. However, some locations such as active construction sites, typically they require additional maintenance and replacement due to heavy sediment loadings. There are two types of maintenance, minor and major. Minor maintenance usually occurs late in the rainy season and involves the cleanup and removal of vegetation and debris in addition to the determination of the date of major maintenance. During major maintenance, which occurs in late summer or early fall, cartridge replacement and sediment removal occur. (Table 10) shows the optimum time of the year for maintenance activities to take place in the Pacific Northwest.

Table 10: Best annual plan for maintenance activities. (CONTECH. 2016)

\begin{tabular}{||c|c|c|c|c|c|c|c|c|c|c|c||}
\hline \hline \multicolumn{3}{|c|}{ WET } & \multicolumn{3}{c|}{ WET } & \multicolumn{3}{c||}{ DRY } & \multicolumn{3}{c||}{ WET } \\
\hline \multirow{2}{*}{ JAN } & FEB & MAR & APR & MAY & JUN & JUL & AUG & SEP & OCT & NOV & DEC \\
\hline & & $\mathrm{X}$ & $\mathrm{X}$ & $\mathrm{X}$ & $\mathrm{X}$ & $\mathbf{X X}$ & $\mathbf{X X}$ & XX & XX & & \\
\hline
\end{tabular}

$\mathrm{X}=$ Minor maintenance inspection during one of these months. $\mathrm{XX}=$ Major maintenance during one of these months. 
Indications for the need of maintenance include:

- Decreased flow of the effluent below the design flow rate.

- Accumulated vault sediment depths exceed an average of 2 inches.

- Accumulated sediment depths on the tops of the cartridges exceed an average of 0.5 inches.

- Standing water remains in the vault between rain events.

- Bypass occurs during storms smaller than the designed storm.

(Table 11) summarizes the activities associated with StormFilter maintenance

Table 11: StormFilter maintenance activities (CONTECH. 2016)

\begin{tabular}{||c|l|l|l||}
\hline $\begin{array}{c}\text { Facility Component } \\
\text { Requiring } \\
\text { Maintenance }\end{array}$ & \multicolumn{1}{|c||}{$\begin{array}{c}\text { Maintenance } \\
\text { Activity }\end{array}$} & $\begin{array}{c}\text { When Maintenance Activity } \\
\text { Is Required/Action taken }\end{array}$ & $\begin{array}{c}\text { Expected Facility } \\
\text { Performance After } \\
\text { Maintaining }\end{array}$ \\
\hline \hline $\begin{array}{c}\text { StormFilter Cartridges } \\
\text { and Vault }\end{array}$ & $\begin{array}{l}\text { Inspection/Minor } \\
\text { Maintenance: } \\
\text { Trash and Debris } \\
\text { Removal }\end{array}$ & $\begin{array}{l}\text { When large amounts of } \\
\text { floatable objects or other } \\
\text { trash is present in the filter. }\end{array}$ & No change \\
\hline $\begin{array}{c}\text { StormFilter Cartridges } \\
\text { and Vault }\end{array}$ & $\begin{array}{l}\text { Major Maintenance: } \\
\text { Cartridge Replacement } \\
\text { and Sediment Removal }\end{array}$ & $\begin{array}{l}\text { Yearly or every other year, or } \\
\text { when sediment accumulation } \\
\text { in cartridge bay of vault 6" or } \\
\text { more. }\end{array}$ & $\begin{array}{l}\text { New media is able to } \\
\text { effectively treat } \\
\text { stormwater. }\end{array}$ \\
\hline \hline $\begin{array}{c}\text { Drainage System } \\
\text { Piping }\end{array}$ & Flushing With Water & $\begin{array}{l}\text { If drainage system is } \\
\text { obstructed by debris or } \\
\text { sediment. }\end{array}$ & $\begin{array}{l}\text { Outflow is not } \\
\text { restricted. }\end{array}$ \\
\hline \hline
\end{tabular}




\subsection{PERFORMANCE TEST SITES DESCRIPTION}

StormFilter with ZPG media received Washington GULD approval in January 2005, based on a field study conducted at five locations, but the results of only two, site A (Heritage Marketplace Field Evaluation) and site E (Lake Stevens Field Evaluation) were taken because they were the only testing locations using ZPG media. The sites used for the study were chosen based on their suitability for a long-time monitoring project. Historical maintenance records and preliminary site surveys were conducted to confirm the suitability of the sites for TSS performance evaluation. A brief description of the stormFilter-ZPG installed at each location is described below.

\subsection{Heritage Marketplace}

The Heritage Marketplace StormFilter system was installed in a parking lot area, close to a large grocery store with many smaller businesses with high traffic density during normal business hours. The StormFilter installed at Heritage Marketplace consists of vault housing 23 cartridges, with dimensions of 2.4-m x 4.9-m (8-ft x 16- ft). Each cartridge operated at a filtration rate of 7.5-gpm (28 L/min), yielding a peak operation rate of $640 \mathrm{~L} / \mathrm{min}$ which is approximately $5 \%$ less than the $680 \mathrm{~L} / \mathrm{min}$, peak system operation rate recommended for the site based upon the sizing standards specified by Ecology. The StormFilter system treats runoff from 16,000-m $\mathrm{m}^{3}(4.0-\mathrm{ac})$, primarily from impervious surfaces such as parking lots. Main sources of pollutants in this drainage area include trash, metals, solids, and automobile waste, site maintenance events, seasonal activities, and atmospheric fallout. Filtered runoff is discharged directly into an on-site infiltration gallery (CONTECH product evaluation. 2006). (Figure 10) below shows the location of the installed stomFilter. 


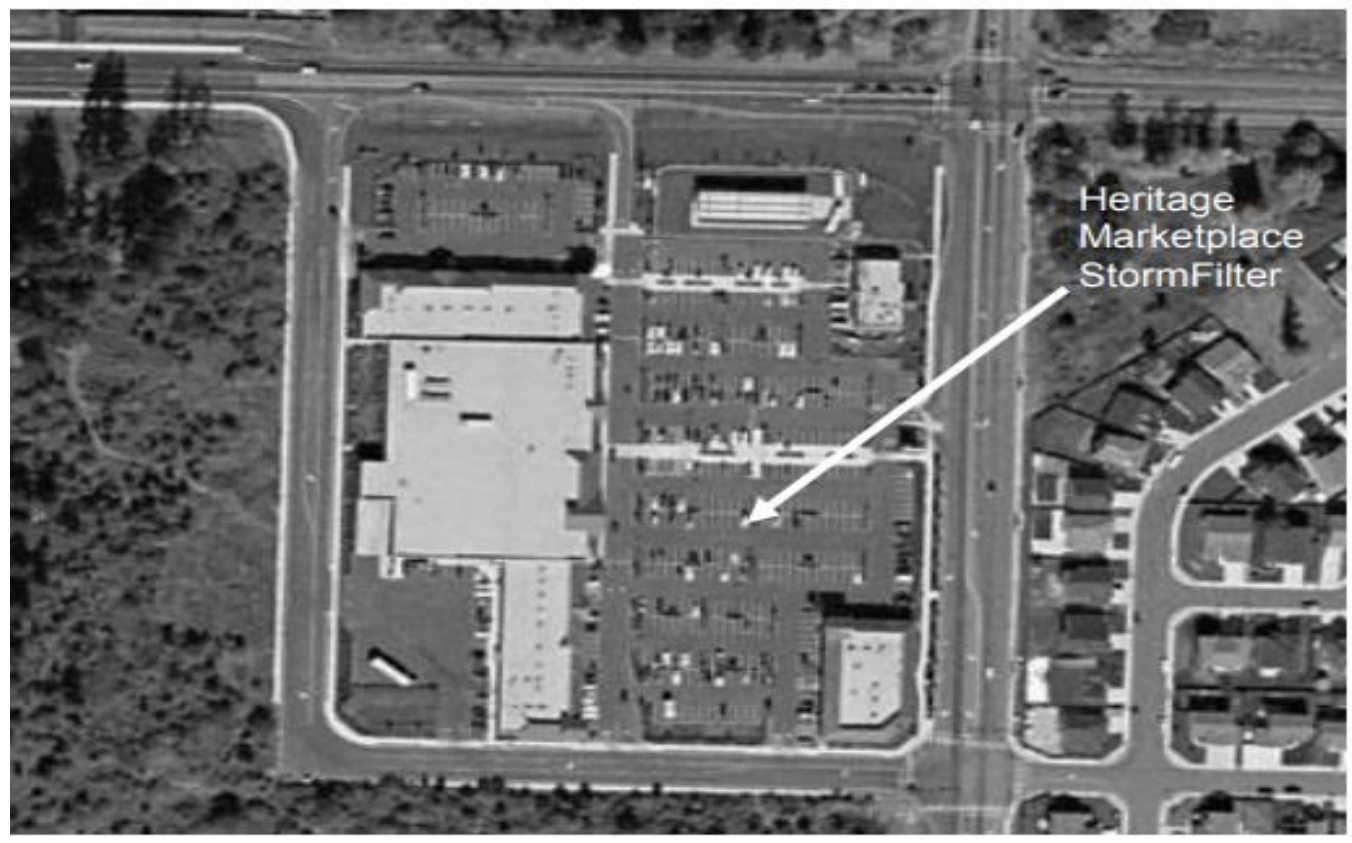

Figure 10: Aerial view of the Heritage Marketplace StormFilter site (CONTECH product evaluation. 2006)

\subsection{Lake Stevens}

The Lake Stevens StormFilter system was placed by the side of Lake Stevens, east of South Lake Stevens Road in the vicinity of the north end of the bridge deck. The drainage area is $1,200 \mathrm{~m}^{3}$ $(0.29 \mathrm{ac})$ of $100 \%$ impervious arterial-road bridge decking and adjacent roadway. Primary sources of pollutants in this area include solids, metals, trash, and debris from automobiles, maintenance activities, and atmospheric fallout. Filtered runoff is discharged directly into the adjacent lake (CONTECH product evaluation. 2006). The StormFilter installed at Lake Stevens consists of vault housing ten cartridges, with dimensions of 1.8-m x 3.7-m (6-ftx12-ft). Each cartridge operated at a filtration rate of $7.5-\mathrm{gpm}(28 \mathrm{~L} / \mathrm{min})$, yielding a peak operation rate of $280 \mathrm{~L} / \mathrm{min}$ which is approximately $10 \%$ less than the $320 \mathrm{~L} / \mathrm{min}$, peak system operation rate is recommended for the site based upon the sizing standards specified by Ecology. (Figure 11) below shows the location of Lake Stevens stomFilter site. 


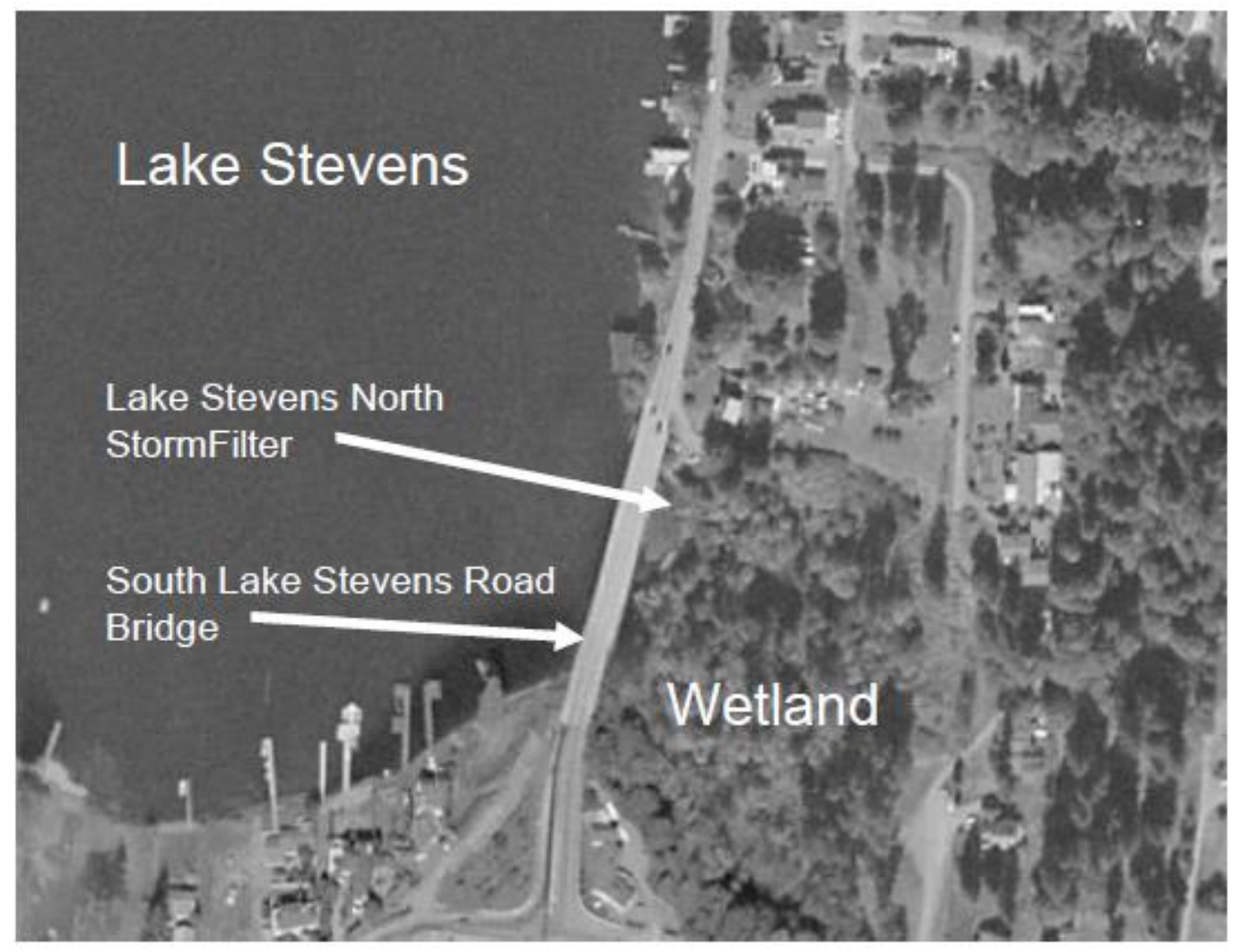

Figure 11: Aerial view of the Lake Stevens North StormFilter site (CONTECH product evaluation. 2006).

The two selected sites are entirely different. The Heritage site is a parking lot of a shopping mall, (Heritage site) with a low concentration of coarse sediments, mainly because stormwater moves like a thin sheet of flow across the pavement. The bridge site, (Lake Stevens) has a daily traffic of 10,000 vehicles/day with a much coarser influent sediment. A comparison between the characteristics of the two sites is provided in (Table 12).

Table 12: Sediment size comparison between the two sites (CONTECH application. 2016)

\begin{tabular}{lcc}
\hline & LAKE STEVENS & HERITAGE \\
\hline Sediment $\%>100$ microns & $35 \%$ & $12 \%$ \\
\hline Sediment $\%>500$ microns $^{2}$ & $15 \%$ & $4 \%$ \\
\hline${\text { TSS } \%>500 \text { microns }^{\mathrm{a}}}^{\mathrm{a}}$ & $10 \%$ & $11 \%$ \\
\hline TSS median $^{\mathrm{a}}$ & $89 \mathrm{mg} / \mathrm{L}$ & $52 \mathrm{mg} / \mathrm{L}$ \\
\hline
\end{tabular}

a. Of all sampled storms 


\subsection{STORMFILTER - ZPG MEDIA TESTING PERFORMANCE}

CONTECH sampled 32 storms between April 2003 to March 2004. However, only 22 storms met

TAPE requirements in the October 2002 version of the Guidance for Evaluating Emerging

Stormwater Treatment Technologies. TAPE minimum criteria for the sampled storm are:

- Minimum storm depth -0.15 inches;

- Minimum storm runoff duration - one hour;

- Antecedent condition - not more than 0.06 inches during the 6 hours preceding the sampled storm;

- For TSS, 12 to 35 events are tested, the specific minimum number dependent upon the coefficient of variation observed at the test sites.

The guidelines are:

- For each sampled storm, at least ten aliquots are retrieved to produce the flow- weighted composite sample;

- The aliquots are obtained over at least $75 \%$ of the volume of the sampled storm. The qualified storms and other event characteristics are summarized in ( Table 13) below. 
Table 13: Qualified storms with aggregate TSS load reduction (CONTECH application. 2016)

\begin{tabular}{|c|c|c|c|c|c|c|c|}
\hline & & & & \multicolumn{4}{|c|}{ TSS-WA EMCs by Category } \\
\hline & \multirow{2}{*}{$\begin{array}{l}\text { Normalized, } \\
\text { Sampled Influen! }\end{array}$} & \multicolumn{2}{|c|}{ ALL } & \multicolumn{2}{|c|}{$\operatorname{lnf} E M C<100$} & \multicolumn{2}{|c|}{$\mid n f E M C>100$} \\
\hline & & & & & & & \\
\hline & Volume & Influen & Effluen & nfluen & Effluer & nfluen & Effluent \\
\hline Qualifying Event ID & gallcartiridge & mgll & mgll & mgll & mgll & mgll & mgll \\
\hline $\mathrm{HMP050303}$ & 842 & 66.4 & 28.3 & 66.4 & 28.3 & NA & NÁ \\
\hline HMP050703 & 1033 & 519 & 23 & NA & NA & 519 & 23 \\
\hline LSN051503 & 123 & 120 & 29 & NA & NA & 120 & 29 \\
\hline HMP090703 & 270 & 378 & 37.2 & NA & NA & 378 & 37.2 \\
\hline HMP090903 & 428 & 76.9 & 16 & 76.9 & 16 & NA & NÁ \\
\hline HMP091603B & 363 & 96.9 & 31.2 & 96.9 & 31.2 & NA & NA \\
\hline LSN091603 & 250 & 99 & 21 & 99 & 21 & NA & NÁ \\
\hline HMP100603 & 433 & 117 & 41.1 & NA & NA & 117 & 41.1 \\
\hline LSN100603 & 158 & 83 & 22 & 83 & 22 & NA & NA \\
\hline HMP100903A & 307 & 83.6 & 40.4 & 83.6 & 40.4 & NA & NA \\
\hline HMP101103 & 481 & 7.53 & 4.86 & 7.53 & 4.86 & NA & NA \\
\hline HMP102203 & 463 & 22.1 & 9.59 & 22.1 & 9.59 & NA & NA \\
\hline LSN102203 & 330 & 95 & 11 & 95 & 11 & NA & NA \\
\hline HMP111003 & 332 & 30.6 & 22.3 & 30.6 & 22.3 & NA & NA \\
\hline LSN111003 & 1112 & 26 & 10 & 26 & 10 & NA & NA \\
\hline HMP111503 & 540 & 6.85 & 6.16 & 6.85 & 6.16 & NA & NA \\
\hline LSN120203 & 465 & 264 & 32.6 & NA & NA & 264 & 32.6 \\
\hline HMP121003 & 710 & 28 & 17.2 & 28 & 17.2 & NA & NA \\
\hline HMP121603 & 540 & 45.9 & 18.8 & 45.9 & 18.8 & NA & NA \\
\hline LSN012204 & 268 & 54 & 46 & 54 & 46 & NA & NA \\
\hline LSN012904 & 473 & 170 & 48 & NA & NA & 170 & 48 \\
\hline LSN030604 & 170 & 120 & 26 & NA & NA & 120 & 26 \\
\hline Average EMC (mal') : & & 114 & 25 & 55 & 20 & 241 & $\overline{34}$ \\
\hline Aggregate Pollutant Lo & Aeduction\%: & & & & & & \\
\hline
\end{tabular}

Seven of the qualified storms had an influent TSS exceeding $100 \mathrm{mg} / \mathrm{L}$, reaching $519 \mathrm{mg} / \mathrm{L}$. For this range of TSS, the average influent and effluent concentrations and aggregate pollutant load reduction are $241 \mathrm{mg} / \mathrm{L}, 34 \mathrm{mg} / \mathrm{L}$, and $89 \%$ respectively. Two out of the previous seven storm events had an influent TSS exceeding Ecology's guidelines of $300 \mathrm{mg} / \mathrm{L}$, so by eliminating those storms, all the numbers will change, yielding an average influent and effluent concentrations and aggregate pollutant reduction of $158 \mathrm{mg} / \mathrm{L}, 35 \mathrm{mg} / \mathrm{L}$, and $78 \%$, respectively. The remaining 15 
qualified storms had influent TSS less than $100 \mathrm{mg} / \mathrm{L}$ reaching $6.85 \mathrm{mg} / \mathrm{L}$, so the average influent and effluent concentrations and aggregate pollutant load reduction are $55 \mathrm{mg} / \mathrm{L}, 20 \mathrm{mg} / \mathrm{L}$, and $61 \%$ respectively. Six out of the 15 events have TSS concentrations below Ecology's guidelines of 33 $\mathrm{mg} / \mathrm{L}$. So, by excluding them, the concentrations and the pollutant load reductions have changed to be $78 \mathrm{mg} / \mathrm{L}, 26 \mathrm{mg} / \mathrm{L}$ and $67 \%$ for the average influent and effluent TSS and the pollutant load reduction respectively.

CONTECH explained in their application that none of the methods used to measure the performance goal of the stormfilter are applicable at an influent concentration below $100 \mathrm{mg} / \mathrm{L}$. However, there is a simpler approach that involves determining the number of storms with influent TSS less than $100 \mathrm{mg} / \mathrm{L}$ that had an effluent TSS at or near $20 \mathrm{mg} / \mathrm{L}$. In addition, they provided the table below, (Table 14), summarizes the annual average TSS- removal efficiency of the stormfilters during TAPE testing period.

Table 14: Efficiency Calculations Submitted by Stormwater Management, Inc. as part of the WA DOE TAPE Technical Evaluation Report (TER) for the StormFilter with ZPG (2004a).

\begin{tabular}{|c|c|}
\hline \multicolumn{2}{|c|}{ Influent TSS-WA EMC $(\mathrm{mg} / \mathrm{L})$} \\
\hline$<100$ & $>100$ \\
\hline $\begin{array}{l}\text { Approximately } 70 \% \text { of the qualifying events } \\
\text { fall into this category. Of these, } \\
\text { approximately half demonstrate effluent } \\
\text { EMCs less than } 20 \mathrm{mg} / \mathrm{L} \text {. An arithmetic } \\
\text { average of effluent EMCs under this } \\
\text { category yields an annual average effluent } \\
T S S-W A \text { EMC of } 20 \mathrm{mg} / \mathrm{L}(n=15) \text {. }\end{array}$ & $\begin{array}{l}\text { Only the aggregate pollutant loading } \\
\text { reduction calculation (Method \#2) } \\
\text { recommended by WADOE (2002) } \\
\text { produces a singular performance value } \\
\text { on an annual average basis. The } \\
\text { resulting performance for this category is } \\
\text { an annual average removal of } 89 \%(n=7) \text {. }\end{array}$ \\
\hline
\end{tabular}

As seen in (Table 14), for TSS < 100 the average effluent was less than $20 \mathrm{mg} / \mathrm{L}$. Moreover, for TSS $>100 \mathrm{mg} / \mathrm{L}$ the aggregate removal reduction was $89 \%$, which indicates that the StormFilter met the WA TAPE requirements for TSS removal. 
The following graph, generated by the author, presents a comparison of the City of Portland's treatment requirements with the performance of the StormFilter with ZPG for the 22 qualifying storms. Most of the effluent concentrations meet Portland's treatment standard, but there are some exceedances.

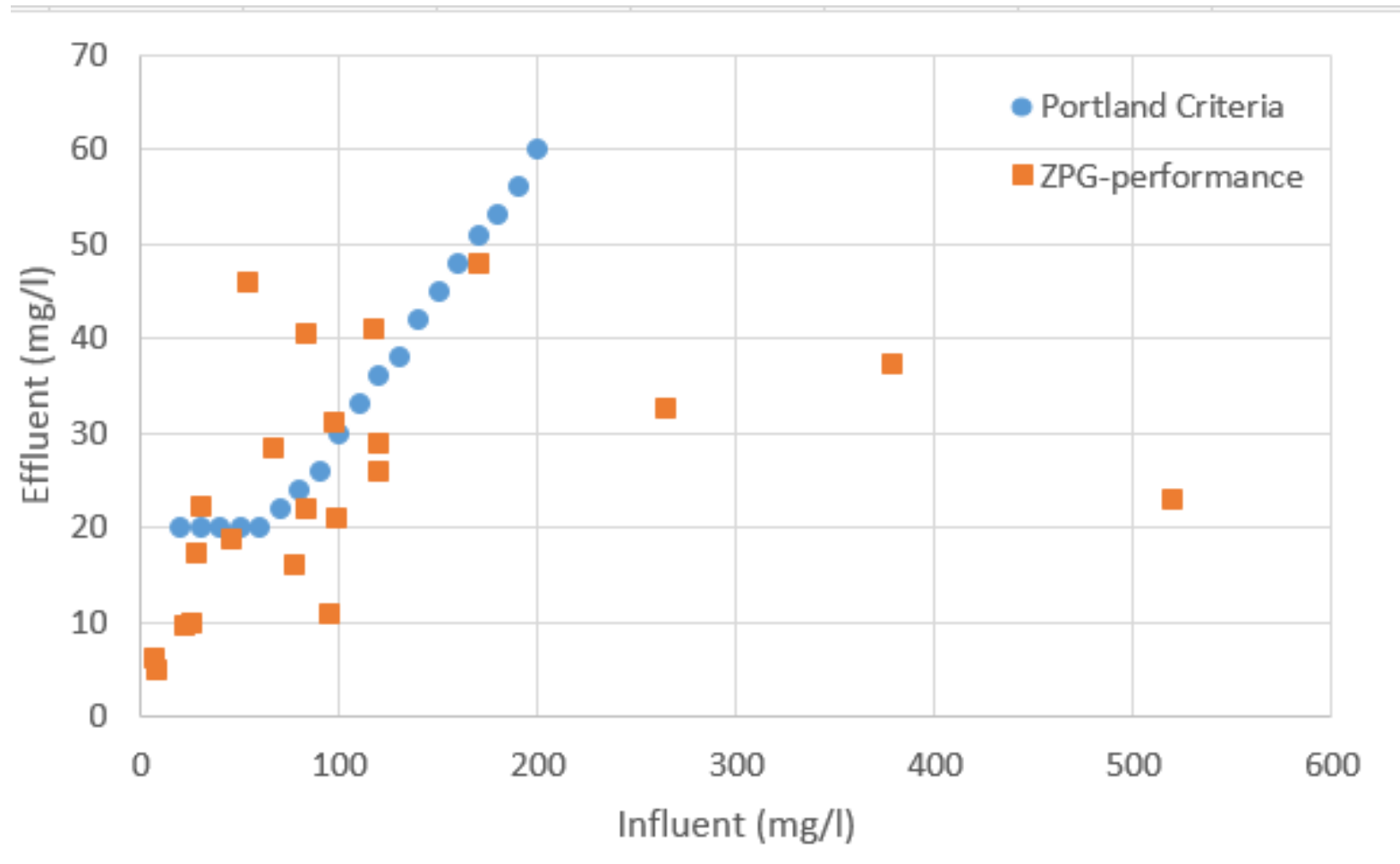

Figure 12: The graph compares the City of Portland's treatment criteria against the performance of the ZPGfilter. Most of the storm effluent concentrations lie below Portland's criteria. 


\subsection{REVIEW\& EVALUATION FINDINGS}

The City of Portland's SWMM requirements for TSS removal are slightly different from TAPE requirements, and according to (Table 14) above, StormFilter (ZPG) meets them all. However, (Table 14 )is biased for two reasons:

1. For influent TSS $<100 \mathrm{mg} / \mathrm{L}$, all storms even the ones that are below $33 \mathrm{mg} / \mathrm{L}$. were used, (Table 13). There were storms with an influent as low as $6.85 \mathrm{mg} / \mathrm{L}$, in which their effluent did not change much to be $6.16 \mathrm{mg} / \mathrm{L}$. So, including these low effluent concentrations will indeed yield a low arithmetic average of effluent EMCs of $20 \mathrm{mg} / \mathrm{L}$.

2. For influent TSS $>100 \mathrm{mg} / \mathrm{L}$, all storms, even the ones that were above $300 \mathrm{mg} / \mathrm{L}$, were used, (Table 13). There were storms with an influent as high as $519 \mathrm{mg} / \mathrm{L}$, in which their effluent decreased dramatically after filtration, reaching $23 \mathrm{mg} / \mathrm{L}$. Including these high pollutant reductions in the calculations will yield a high removal efficiency of $89 \%$.

The following table compares WA TAPE's treatment goals, Portland's treatment requirements, and a summary of the TAPE performance information presented in the previous section.

Table 15: WA TAPE Goals vs. Portland Requirements vs. TAPE Testing Results for the StormFilter with ZPG

\begin{tabular}{|c|l|l|l|}
\hline & WA TAPE Goals & $\begin{array}{l}\text { Portland } \\
\text { Requirement }\end{array}$ & ZPG Filter Performance \\
\hline TSS & $\begin{array}{l}80 \% \text { removal with } \\
\text { influent concentration } \\
100-200 \mathrm{mg} / \mathrm{L}\end{array}$ & $\begin{array}{l}70 \% \text { removal if } \\
\text { influent concentration } \\
\text { is }>70 \mathrm{mg} / \mathrm{L}\end{array}$ & $\begin{array}{l}\text { TER Submittal } \\
89 \% \text { removal for influent concentration } \\
>100 \mathrm{mg} / \mathrm{L} ;<20 \mathrm{mg} / \mathrm{L} \text { for influent } \\
<100 \mathrm{mg} / \mathrm{L} .\end{array}$ \\
& $\begin{array}{c}<20 \mathrm{mg} / \mathrm{L} \text { if influent } \\
\text { concentration }<100 \mathrm{mg} / \mathrm{L}\end{array}$ & $\begin{array}{l}<2 \mathrm{mg} / \mathrm{L} \text { with influent } \\
<100 \mathrm{mg} / \mathrm{L}\end{array}$ & $\begin{array}{l}\text { WA DOE Findings of Fact } \\
78 \% \text { removal for influent concentration }> \\
100 \mathrm{mg} / \mathrm{L} \text { (excluding storms exceeding } \\
\end{array}$ \\
& & $\begin{array}{l}\text { Ecology guideline of } 300 \mathrm{mg} / \mathrm{L} \text { ). } \\
26 \% \text { mg/L for influent }<100 \mathrm{mg} / \mathrm{L} \\
\text { (excluding storms below Ecology } \\
\text { guideline of } 33 \mathrm{mg} / \mathrm{L}) .\end{array}$ \\
\hline
\end{tabular}


As shown in Table 15, when the six storms with influent concentrations $<33 \mathrm{mg} / \mathrm{L}$ were excluded from the data analysis, ZPG filter performance $(26 \mathrm{mg} / \mathrm{L})$ exceeded the $<20 \mathrm{mg} / \mathrm{L}$ TAPE criterion for storms with influent concentrations $<100 \mathrm{mg} / \mathrm{L}$. However, in the 2005 Findings of Fact, the WA DOE Technical Review Committee relied upon the weight of evidence and best professional judgment for approving the Stormfilter with ZPG filter media. Other factors used in the decision to support the Stormfilter included:

- Results of data analysis in aggregate;

- Data analysis with events near the Stormfilter design flow rate more heavily weighted;

- During sub-design flow rate periods, different cartridges within the Stormfilter vault may be operating at different flow rates (some with open float valves while others are closed and running at a "trickle" flow rate;

- Laboratory testing of silica product resulted in $87 \%$ TSS removal at $100 \%$ design flow rate; and

- Additional testing at three sites, (The I-5 Lake Union, Greenville Yards (New Jersey) and Ski Run Marina (Lake Tahoe) facilities show consistent TSS removals in the 75 to $85 \%$ range. Showed consistent TSS removals between $75 \%$ and $85 \%$. 


\subsection{CONCLUSION}

The results of the TAPE evaluation and review of additional submittal information suggests the StormFilter generally meets Portland's treatment standard for TSS removal. Consistent with the WA DOE approval, the recommendation was to approve the device for use in the City of Portland at the TAPE-approved flow rate of $1 \mathrm{gpm} / \mathrm{ft}^{3}$. Using the cartridge flow rates provided in Table 9, a Portland-specific sizing table should be developed to assist designers with preliminary sizing and cost estimates based on Portland's design storm and sizing methods. 


\subsection{REFERENCES}

Brown, N.J. \& Peake, B. M. (2005). "Sources of heavy metals and polycyclic aromatic hydrocarbons in urban stormwater runoff." Science of The Total Environment, 359 (2006) 145155 .

City of Portland. 2016. Stormwater Management Manual, Appendix B: Manufactured Stomate Treatment Technologies. City of Portland Bureau of Environmental Services, Portland, Oregon. CONTECH Engineered Solution. (2016). "Stormwater Treatment for the Most Challenging Pollutants", http://www.conteches.com/products/stormwater-management/treatment/stormwatermanagement-stormfilter (accessed March 20th, 2017).

Ecology. 2008. Guidance for Evaluating Emerging Stormwater Treatment Technologies: Technology Assessment Protocol-Ecology (TAPE). Publication No. 02-10-037, Washington State Department of Ecology, Olympia, Washington.

Hoppin, M. (2008). Guidance for Evaluating Emerging Stormwater Treatment Technologies, Technology Assessment Protocol - Ecology (TAPE) Olympia, Washington: Washington State Department of Ecology.

Howie, D. C. (2011). Technical Guidance Manual for Evaluating Emerging Stormwater Treatment Technologies, Technology Assessment Protocol - Ecology (TAPE)Olympia, Washington: Washington State Department of Ecology.

Kavianpour Isfahani, Zahra, "Statistical Analysis of Stormwater Device Testing Protocols in Portland, Oregon" (2013). Dissertations and Theses. Paper 676.

http://pdxscholar.library.pdx.edu/open_access_etds/676 10.15760/etd.676

Lee, G. F. \& Johns-Lee, A. (2005). “Urban Stormwater Runoff Water Quality Issues,” Water Encyclopedia: Surface and Agricultural Water, Report of G. Fred Lee \& Associates, El Macero, CA 95618. http://www.gfredlee.com/Runoff/WileyStormwater.pdf

Liu, A., Li, D., Liu, L.\& Guan, Y. (2014). "Understanding the Role of Urban Road Surface Characteristics in influencing Stormwater Quality." Water Resource Management, 28:52175229.

Novotny, E.V., Murphy, D. \& Stefan, H.G. (2008). "Increase of urban lake salinity by road deicing salt." Science of The Total Environment, 406(1-2), 131-144.

StormFilter with ZPG Media. 2016. Re-Application letter to City of Portland BES. CONTECH, Portland, Oregon. December 21st, 2016.

Tsihrintzis, V. A. \&Hamid, R. (1997). Modeling and management of urban stormwater runoff quality: A review. Water Resources Management 11(2): 136-164. 
Watts, A. W., Ballestero, TH. P., Roseen, M.R. \& Houle, J.P. (2010). "Polycyclic Aromatic Hydrocarbons in Stormwater Runoff from Sealcoated Pavements." ENVIRONMENTAL SCIENCE \& TECHNOLOGY, 44 8849-8854.

https://collaborate.ewrinstitute.org/HigherLogic/System/DownloadDocumentFile.ashx?Documen tFileKey=c468710e-971d-4284-a052-0efae9e25d3d\&forceDialog=0

http://www.conteches.com/DesktopModules/Bring2mind/DMX/Download.aspx?Command=Cor e_Download\&EntryId=2821\&language=en-US\&PortalId=0\&TabId=144 


\subsection{APPENDIX - MORE ADDITIONAL INFORMATION}

\subsection{Final report submitted to the City of Portland.}

\section{Evaluating the performance of Contech's StormFilter with ZPG Media under the City of Portland's 2016 Stormwater Management Manual requirements for manufactured stormwater treatment technologies}

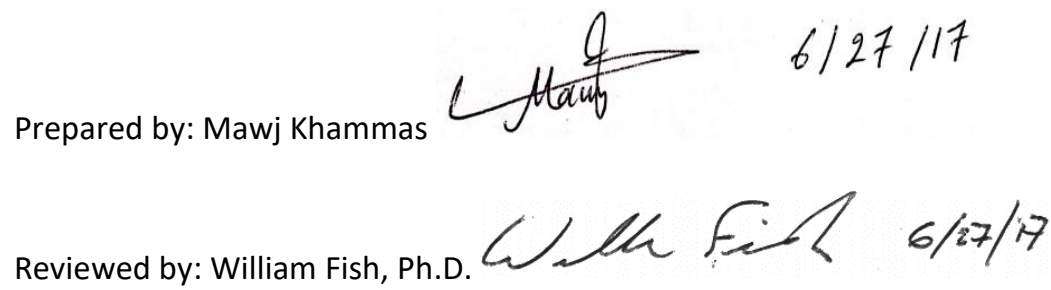

\begin{tabular}{|l|l|}
\hline Document Milestone & Deadline/Date \\
\hline Draft Report submitted to the city & $5 / 23 / 2017$ \\
\hline Comments submitted by city & $6 / 8 / 2017$ \\
\hline Final submitted to city & $6 / 27 / 2017$ \\
\hline
\end{tabular}

\section{Report Objective}

Review the reported performance of the StormFilter ${ }^{\circledR}$ with ZPG media with respect to Portland's pollution reduction requirements, as prescribed in the 2016 Stormwater Management Manual (SWMM).

The 2016 SWMM pollution reduction requirements are:

- $70 \%$ removal of total suspended solids (TSS) from $90 \%$ of the average annual runoff.

- In watersheds that have established total maximum daily loads (TMDLs) or that are on Oregon Department of Environmental quality 303(d) list of impaired waters, stormwater management facilities must be capable of reducing the pollutant(s) of concern.

- Have a current General Use Level Designation (GULD) for Basic Treatment, from the Washington State Department of Ecology (WA DOE) under the Technology Assessment Protocol-Ecology (TAPE), prior to application and review by the City of Portland.

The City of Portland reviews manufactured stormwater treatment technologies under the submittal and review criteria in Chapter 2 of the SWMM. 


\section{Description of the Manufactured Stormwater Treatment Technology}

The StormFilter is an inline, media-filled cartridge system which removes pollutants from stormwater runoff. The system is housed in a precast concrete vault that can be designed in multiple configurations and sizes. Each filter is designed to treat a specific flow rate, which can be controlled through a calibrated reducer disk placed at the base of the cartridge. StormFilters may include an internal bypass in case flow rates exceed the capacity of the cartridges. In case the site generates flow that exceeds the internal bypass capacity, a peak diversion configuration must be used which integrates the diversion weir with the filter bay into the same vault structure. The StormFilter ${ }^{\circledR}$ with ZPG, which is the subject of this review, is specifically designed to remove Total Suspended Solids (TSS) from stormwater runoff. The media is comprised of zeolite, perlite, and granular activated carbon (GAC). The outer layer is $100 \%$ perlite; the inner layer is a mixture of $90 \%$ Zeolite and 10\% GAC. A number of physical processes contribute to treatment of the stormwater: filtration, by trapping the suspended particles in the ZPG media, ion exchange, adsorption and precipitation for larger particles. Cartridges are housed in a vault and receive stormwater horizontally through the inlet pipe. Stormwater passes through the filtration media (ZPG) and begins filling the cartridge's center tube. When water reaches the top of the cartridge, the float valve opens, and filtered water can drain at the design flow rate. Filtered water then discharges out of the system through the under-drain manifold. When the water level outside the cartridge approaches the bottom of the hood, air rushes through the scrubbing regulators, releasing the water column and breaking the siphon. The turbulent bubbling action agitates the surface of the filter media, promoting trapped sediment to drop to the vault floor. This patented surface cleaning mechanism helps restore the permeability of the filter surface between storm events.

\section{StormFilters - ZPG media sizing protocol}

The applicant's submittal to the City of Portland didn't include a Portland-specific sizing table.

The applicant provided the following reference table, which is based on the $1 \mathrm{gpm} / \mathrm{sf} 2$ approved by the WA DOE TAPE program (Table 1). 
Table 1. Approved GULD rates per cartridge at $1 \mathrm{GPM} / \mathrm{FT}^{2}$

\begin{tabular}{|l|c|c|c|}
\hline Effective Cartridge Height (inches) & 12 & 18 & 27 \\
\hline Cartridge Flow Rate (gpm/cartridge) & 5 & 7.5 & 11.3 \\
\hline
\end{tabular}

\section{Summary of StormFilter - ZPG media performance data}

The StormFilter with ZPG media received WA DOE GULD for Basic Treatment approval in January 2005, based on field studies conducted at two sites, Site A (Heritage Marketplace), and Site E (Lake Stevens). CONTECH sampled 32 storms between April 2003 and March 2004. Out of those 32 storms, 22 storms met the TAPE requirements provided by Ecology in the October 2002 version of the Guidance for Evaluating Emerging Stormwater Treatment Technologies. The TAPE minimum criteria for the sampled storms were:

Minimum storm depth -0.15 inches;

Minimum storm runoff duration - one hour;

Antecedent condition - not more than 0.06 inches during the 6 hours preceding the sampled storm;

With respect to TSS, 12 to 35 events are sampled, the specific minimum number dependent upon the Coefficient of Variation observed at the test sites.

The guidelines were:

For each sampled storm, at least 10 aliquots are retrieved to produce the flow weighted composite sample;

The aliquots are obtained over at least $75 \%$ of the volume of the sampled storm.

The qualified storms are listed in the Table 2, below. 
Table 2. Qualified storms with aggregate TSS load reduction

\begin{tabular}{|c|c|c|c|c|c|c|c|}
\hline & & \multirow{2}{*}{\multicolumn{2}{|c|}{ ALL }} & \multicolumn{4}{|c|}{ TSS-WA EMCs by Category } \\
\hline & Normalized, & & & \multicolumn{2}{|c|}{$\operatorname{lnf} E M C<100$} & \multicolumn{2}{|c|}{$\mid n f E M C>100$} \\
\hline \multicolumn{2}{|c|}{ Sampled Influen' } & & & & & & \\
\hline & Volume & Influen & Effluer & Influen & Effluer & Influer & Effluent \\
\hline Qualifying Event ID & gallcartiridge & mgll & mgll & mgll & mgll & mgll & mgll \\
\hline HMP050303 & 842 & 66.4 & 28.3 & 66.4 & 28.3 & NÁ & NA \\
\hline HMP050703 & 1033 & 519 & 23 & NA & NÁ & 519 & 23 \\
\hline LSN051503 & 123 & 120 & 29 & NA & NA & 120 & 29 \\
\hline HMP090703 & 270 & 378 & 37.2 & NA & NA & 378 & 37.2 \\
\hline HMP090903 & 428 & 76.9 & 16 & 76.9 & 16 & NA & NA \\
\hline HMP091603B & 363 & 96.9 & 31.2 & 96.9 & 31.2 & NÁ & NA \\
\hline LSN091603 & 250 & 99 & 21 & 99 & 21 & NÁ & NA \\
\hline HMP100603 & 433 & 117 & 41.1 & NA & NA & 117 & 41.1 \\
\hline LSN100603 & 158 & 83 & 22 & 83 & 22 & NA & NA \\
\hline HMP100903A & 307 & 83.6 & 40.4 & 83.6 & 40.4 & NA & NA \\
\hline HMP101103 & 481 & 7.53 & 4.86 & 7.53 & 4.86 & NA & NÁ \\
\hline HMP102203 & 463 & 22.1 & 9.59 & 22.1 & 9.59 & NA & NA \\
\hline LSN102203 & 330 & 95 & 11 & 95 & 11 & NÁ & NA \\
\hline HMP111003 & 332 & 30.6 & 22.3 & 30.6 & 22.3 & NA & NA \\
\hline LSN111003 & 1112 & 26 & 10 & 26 & 10 & NÁ & NA \\
\hline HMP111503 & 540 & 6.85 & 6.16 & 6.85 & 6.16 & NÁ & NA \\
\hline LSN120203 & 465 & 264 & 32.6 & NA & NA & 264 & 32.6 \\
\hline HMP121003 & 710 & 28 & 17.2 & 28 & 17.2 & NA & NA \\
\hline HMP121603 & 540 & 45.9 & 18.8 & 45.9 & 18.8 & NA & NA \\
\hline LSN012204 & 268 & 54 & 46 & 54 & 46 & NÁ & NA \\
\hline LSN012904 & 473 & 170 & 48 & NA & NA & 170 & 48 \\
\hline LSN030604 & 170 & 120 & 26 & NA & NA & 120 & 26 \\
\hline "Average EMC (mgl'l): & & 1114 & 25 & 55 & 20 & 241 & $\overline{34}$ \\
\hline \multicolumn{2}{|c|}{ Aggregate Pollutant Load Reduction\%: } & \multicolumn{2}{|c|}{82} & \multicolumn{2}{|c|}{61} & & \\
\hline
\end{tabular}

The characteristics of the two sites were quite different. The Heritage site is a parking lot at a shopping mall, with low concentrations of coarse sediments. The Lake Stevens site is a bridge with a daily traffic count of 10,000 vehicles/day and much coarser influent sediment. A comparison of the characteristics of the two sites is provided below in Table 3 . 
Table 3. Sediment size comparison between the two sites

\begin{tabular}{lcc}
\hline & LAKE STEVENS & HERITAGE \\
\hline Sediment $\%>100$ microns & $35 \%$ & $12 \%$ \\
\hline Sediment $\%>500$ microns $^{2}$ & $15 \%$ & $4 \%$ \\
\hline${\text { TSS } \%>500 \text { microns }^{\mathrm{a}}}^{\text {TSS median }}{ }^{\mathrm{a}}$ & $10 \%$ & $11 \%$ \\
\hline TS $^{\text {O }}$ & $89 \mathrm{mg} / \mathrm{L}$ & $52 \mathrm{mg} / \mathrm{L}$ \\
\hline
\end{tabular}

a. Of all sampled storms

\section{Total Suspended Solid (TSS) Removal}

The following is the TAPE performance goal taken from the Department of Ecology's 2001 Stormwater Manual for Western Washington.

Ecology's basic treatment menu facility choices are intended to achieve a goal of 80 percent removal of total suspended solids for influent concentrations that are greater than $100 \mathrm{mg} / \mathrm{L}$, but less than $200 \mathrm{mg} / \mathrm{L}$. For influent concentrations, greater than $200 \mathrm{mg} / \mathrm{L}$, a higher treatment goal may be appropriate. For influent concentrations, less than $100 \mathrm{mg} / \mathrm{L}$, the facilities are intended to achieve an effluent goal of $20 \mathrm{mg} / \mathrm{L}$ total suspended solids. Flows in excess of the water quality design flow or volume can be bypassed around the facility. The performance goal applies:

- to stormwater with a typical particle size distribution;

- on an annual average basis to the entire discharge volume (treated plus bypassed); and,

- to the water quality design storm volume or flow rate. (Ecology, 2001-Ch.4, Vol.V).

The table below, included in the TAPE technical submittal by the company's consultant, summarizes the annual average TSS-removal efficiency of the StormFilter with ZPG during the TAPE testing period. 
Table 4. Efficiency Calculations Submitted by Stormwater Management, Inc. with the WA DOE TAPE Technical Evaluation Report (TER) for the StormFilter with ZPG (2004a).

\begin{tabular}{|c|c|}
\hline \multicolumn{2}{|c|}{ Influent TSS-WA EMC ( $\mathrm{mg} / \mathrm{L})$} \\
\hline$<100$ & $>100$ \\
\hline $\begin{array}{l}\text { Approximately } 70 \% \text { of the qualifying events } \\
\text { fall into this category. Of these, } \\
\text { approximately half demonstrate effluent } \\
\text { EMCs less than } 20 \mathrm{mg} / \mathrm{L} \text {. An arithmetic } \\
\text { average of effluent EMCs under this } \\
\text { category yields an annual average effluent } \\
\text { TSS-WA EMC of } 20 \mathrm{mg} / \mathrm{L}(n=15) \text {. }\end{array}$ & $\begin{array}{l}\text { Only the aggregate pollutant loading } \\
\text { reduction calculation (Method \#2) } \\
\text { recommended by WADOE (2002) } \\
\text { produces a singular performance value } \\
\text { on an annual average basis. The } \\
\text { resulting performance for this category is } \\
\text { an annual average removal of } 89 \%(n=7) \text {. }\end{array}$ \\
\hline
\end{tabular}

The results summarized in Table 4, using arithmetic averages of effluent EMC's, indicates the StormFilter met the WA TAPE requirements for TSS removal.

The following information is taken directly from WA DOE's' Findings of Fact in the General Use Designation for Basic (TSS) Treatment for the StormFilter with ZPG Media (April 2017; based on $1 \mathrm{gpm} / \mathrm{sf}$ of media surface area). The information forms the technical basis for WA DOE's approval of the device.

- Of the 32 sampling events, 22 met TAPE required storm event conditions with an average influent concentration of $114 \mathrm{mg} / \mathrm{L}$, average effluent concentration of $25 \mathrm{mg} / \mathrm{L}$ and an aggregate pollutant reduction of $82 \%$.

- Seven of the qualified storms had an influent TSS exceeding $100 \mathrm{mg} / \mathrm{L}$, reaching $519 \mathrm{mg} / \mathrm{L}$. For this range of TSS, the average influent and effluent concentration and aggregate pollutant load reduction are $241 \mathrm{mg} / \mathrm{L}, 34 \mathrm{mg} / \mathrm{L}$ and $89 \%$ respectively. Two out of the previous $7 \mathrm{storm}$ events had an influent TSS exceeding Ecology's guidelines of $300 \mathrm{mg} / \mathrm{L}$. Eliminating those 2 storms yields average influent and effluent concentrations and an aggregate pollutant reduction of $158 \mathrm{mg} / \mathrm{L}, 35 \mathrm{mg} / \mathrm{L}$ and $78 \%$, respectively.

- The remaining 15 qualified storms had influent TSS less than $100 \mathrm{mg} / \mathrm{L}$, reaching $6.85 \mathrm{mg} / \mathrm{L}$. The average influent and effluent concentrations and aggregate pollutant load reduction were $55 \mathrm{mg} / \mathrm{L}, 20 \mathrm{mg} / \mathrm{L}$ and $61 \%$ respectively. Six out of the 15 events have TSS concentrations below Ecology's guidelines of $33 \mathrm{mg} / \mathrm{L}$. Excluding those six storms results in average influent 
and effluent concentrations and an aggregate pollutant load reduction of $78 \mathrm{mg} / \mathrm{L}, 26 \mathrm{mg} / \mathrm{L}$, and $67 \%$, respectively.

The following graph, generated by the author, presents a comparison of the City of Portland's treatment requirements with the performance of the StormFilter with ZPG for the 22 qualifying storms. Most of the effluent concentrations meet Portland's treatment standard, but there are some exceedances.

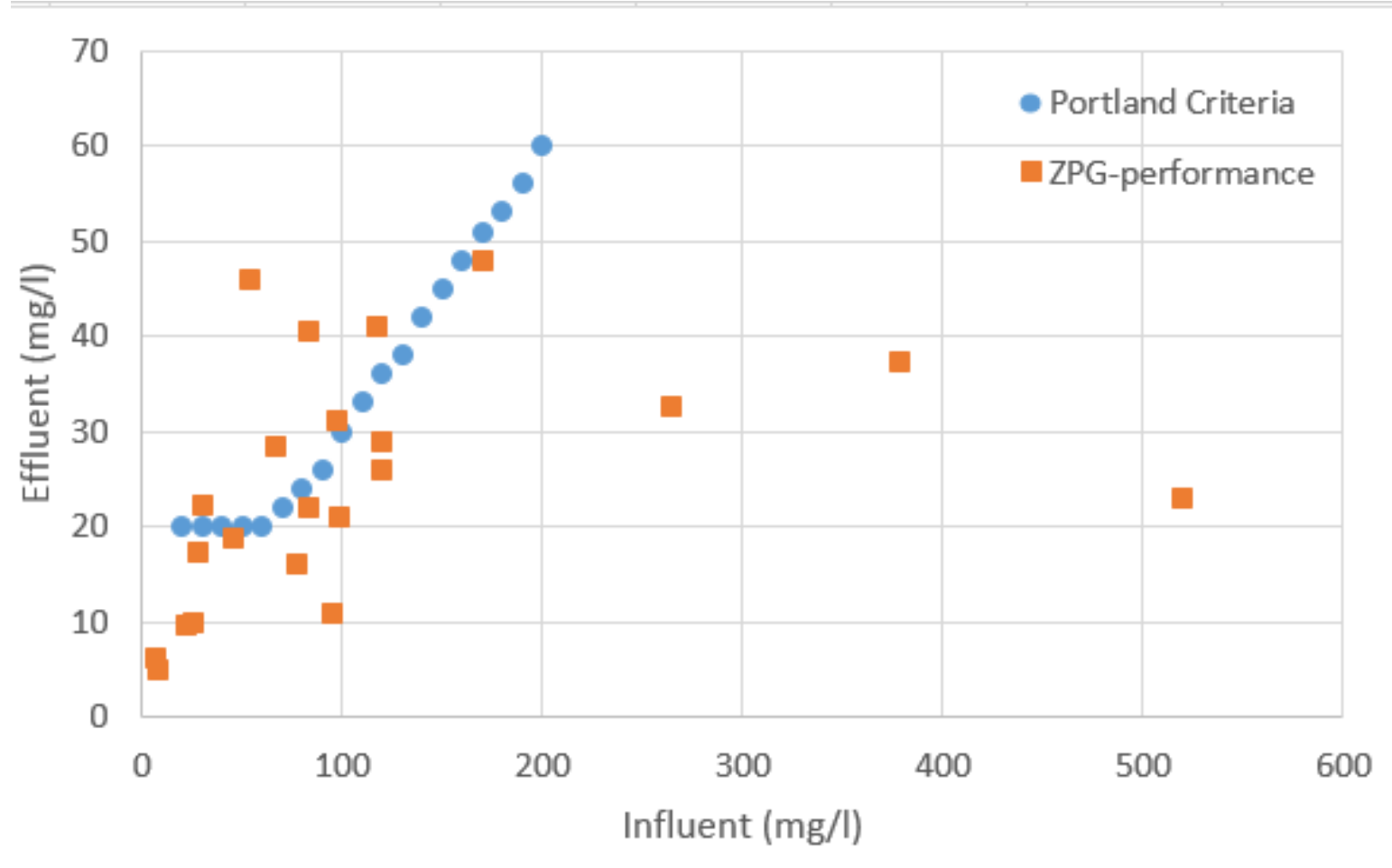

Figure 1. The graph compares the City of Portland's treatment criteria against the performance of the ZPG-filter. Most of the storm effluent concentrations lie below Portland's criteria. 


\section{Review of Findings}

The following table compares WA TAPE's treatment goals, Portland's treatment requirements, and a summary of the TAPE performance information presented in the previous section.

\begin{tabular}{|c|l|l|l|}
\hline TSS & WA TAPE Goals & $\begin{array}{l}\text { Portland } \\
\text { Requirement }\end{array}$ & ZPG Filter Performance \\
\hline Removal & $\begin{array}{l}\text { 80\% removal with } \\
\text { influent concentration } \\
100-200 \mathrm{mg} / \mathrm{L}\end{array}$ & $\begin{array}{l}70 \% \text { removal if } \\
\text { influent concentration } \\
\text { is }>70 \mathrm{mg} / \mathrm{L}\end{array}$ & $\begin{array}{l}\text { TER Submittal } \\
89 \% \text { removal for influent concentration } \\
>100 \mathrm{mg} / \mathrm{L} ;<20 \mathrm{mg} / \mathrm{L} \text { for influent } \\
<100 \mathrm{mg} / \mathrm{L} .\end{array}$ \\
& $\begin{array}{c}<20 \mathrm{mg} / \mathrm{L} \text { if influent } \\
\text { concentration }<100 \mathrm{mg} / \mathrm{L}\end{array}$ & $<20 \mathrm{mg} / \mathrm{L}$ with influent \\
& $<100 \mathrm{mg} / \mathrm{L}$ & $\begin{array}{l}\text { WA DOE Findings of Fact } \\
78 \% \text { removal for influent concentration }> \\
100 \mathrm{mg} / \mathrm{L} \text { (excluding storms exceeding } \\
\text { Ecology guideline of } 300 \mathrm{mg} / \mathrm{L}) . \\
26 \% \mathrm{mg} / \mathrm{L} \text { for influent }<100 \mathrm{mg} / \mathrm{L} \text { (excluding } \\
\text { storms below Ecology guideline of } 33 \mathrm{mg} / \mathrm{L}) .\end{array}$ \\
\hline
\end{tabular}

Table 5. WA TAPE Goals vs. Portland Requirements vs. TAPE Testing Results for the StormFilter with ZPG

As displayed in Table 5, when the six storms with influent concentrations $<33 \mathrm{mg} / \mathrm{L}$ were excluded from the data analysis, ZPG filter performance $(26 \mathrm{mg} / \mathrm{L})$ exceeded the $<20 \mathrm{mg} / \mathrm{L}$ TAPE criterion for storms with influent concentrations < $100 \mathrm{mg} / \mathrm{L}$. However, in the 2005 Findings of Fact the WA DOE Technical Review Committee relied upon weight of evidence and best professional judgement for approving the Stormfilter with ZPG filter media. Other factors used in the decision to approve the Stormfilter included:

- Results of data analysis in aggregate;

- Data analysis with events near the Stormfilter design flow rate more heavily weighted;

- During sub-design flow rate periods, different cartridges within the Stormfilter vault may be operating at different flow rates (some with open float valves while others are closed and operating at a "trickle" flow rate;

- Laboratory testing of silica product resulted in $87 \%$ TSS removal at $100 \%$ design flow rate; and 
- Additional testing at three sites showed consistent TSS removals between $75 \%$ and $85 \%$.

\section{Anticipated Long-term Performance and Maintenance}

The system is designed to trap TSS and other particles through its porous media, and as particles fill filter's openings the flow decreases to eventually calling the need for a cartridge replacement. In general, annual replacement is required for most sites. However, some locations like active construction sites require additional maintenance and replacement due to heavy sediment loadings. There are two types of maintenance, minor and major. Minor maintenance involves the cleanup and removal of vegetation, debris in addition to the determination of the date of major maintenance. During major maintenance, cartridge replacement and sediment removal occurs. Indications for the need of maintenance include:

- Decreased flow of the effluent below the design flow rate.

- Accumulated vault sediment depths exceed an average of 2 inches.

- Accumulated sediment depths on the tops of the cartridges exceed an average of 0.5 inches.

- Standing water remains in the vault between rain events.

- Bypass occurs during storms smaller than the designed storm.

\section{Conclusions and Recommendations}

The results of the TAPE evaluation and review of additional submittal information suggests the StormFilter generally meets Portland's treatment standard for TSS removal. Consistent with the WA DOE approval, the recommendation is to approve the device for use in the City of Portland at the TAPE-approved flow rate of $1 \mathrm{gpm} / \mathrm{sf2}$. Using the cartridge flow rates provided in Table 1, a Portland-specific sizing table should be developed to assist designers with preliminary sizing and cost estimates based on Portland's design storm and sizing methods. 


\section{References}

City of Portland. 2016. Stormwater Management Manual, Appendix B: Manufactured Stomwater Treatment Technologies. City of Portland Bureau of Environmental Services, Portland, Oregon.

CONTECH Engineered Solution. (2016). "Stormwater Treatment for the Most Challenging Pollutants", $<$ http://www.conteches.com/products/stormwatermanagement/treatment/stormwater-management-stormfilter> (accessed March 20th, 2017).

Ecology. 2008. Guidance for Evaluating Emerging Stormwater Treatment Technologies: Technology Assessment Protocol-Ecology (TAPE). Publication No. 02-10-037, Washington State Department of Ecology, Olympia, Washington.

StormFilter with ZPG Media. 2016. Re-Application letter to City of Portland BES. CONTECH, Portland, Oregon. December 21st, 2016.

\subsection{Technical Interview Questions}

PORTLAND'S POLLUTION REDUCTION REQURIEMENTS (TAPE RESULTS) 
1. Please provide sizing table for Portland reflecting the Washington DOE GULD-approved rate of $1 \mathrm{gpm} / \mathrm{sf}$ of filter. There are several references to the $2 \mathrm{gpm} / \mathrm{sf}$ flow rates for which Contech seeks to maintain approval. "Ecology" no longer awards Basic treatment certification for $2 \mathrm{gpm} / \mathrm{sf}$ flow rates, based on the exclusion of single-event modeling. The application explains the "equivalency" between a specific flow rate of $2 \mathrm{gpm} / \mathrm{sf}$ with the conservative BES (SBUH) model and the Ecology (WWHM) model $1 \mathrm{gpm} / \mathrm{sf}$ design flows. Please explain.

2. The PDX Airport example attempts to demonstrate that an equally-sized system can be used for either the SBUH or WWHM flows. Is it accurate to say that under both of these modeled scenarios, the stated system achieves the same level of TSS removal? If so, why not state this explicitly? If not, is it valid to claim a system equivalency?

3. Page 6 of the November 2016 StormFilter GULD indicates that some storms included in Table 2 of The TEER were not qualifying storms due to TSS influent concentrations being either too low ( $<33 \mathrm{mg} / \mathrm{L}$ ) or too high (>300 mg/L). When storms with influent concentrations either too low or too high were excluded from system performance calculations, pollutant load reductions did not meet pollutant load reduction goals as noted in pages $6 \& 7$ of the November 2016 GULD (pages $172 \& 173$ of the submittal). Please discuss why storms that did not qualify based on influent TSS concentrations were used in the original pollutant load reduction calculations. In addition, please discuss why Ecology issued a GULD for the StormFilter when the system did not meet pollution load reduction goals if non-qualifying storms were excluded from the calculations.

\section{DESIGN}

4. What design changes, if any, have been implemented with the StormFilter / ZPG media since its initial City of Portland approval in 2002?

5. The original TEER is from 2004. What kind of feedback have you received from customers, both positive and negative, regarding system performance and what design upgrades and modifications have you made in response to customer feedback, if any?

6. Provide documentation confirming $\mathrm{H}-20$ traffic rating, specified frictional resistance, and ADA compliance for the configurations used in the public right-of-way and pedestrian corridors (curb type and vault type grate covers, lids, pre-cast vault, etc.).

7. The calibrated reducer disk placed at the base of the cartridge is responsible for controlling the individual flow rate in each cartridge. The maximum flow rate through each cartridge can be adjusted between 5 and $15 \mathrm{gpm}$, (Technical Evaluation Report, page 18). Explain and give more details about how it is managed and the possibility for failure in the disk and the consequences?

8. Is the internal bypass capacity for each filter mentioned anywhere (besides the individual details found on the website)? Can external bypass be provided if needed? Similar question for hydraulic head needed for each cartridge size.

\section{MAINTENANCE}

9. The brochure mentions a Sorbent Hood Cover. How does it compare with the standard cover for replacement cost and maintenance frequency? Does it have an "expiration date" beyond which it might deteriorate if installed in a location that has a long maintenance cycle ( 3 to 5 years)?

10. Are the individual cartridges labeled with media type and unit height, so the details can be easily noted during inspection (without making confined space entry), to facilitate ordering the correct replacements?

11. Explain appropriate ways of disposing sediments collected during maintenance from construction sites or others that might have high heavy metal levels, municipal landfill disposal may not be an option. 
12. In general, minor maintenance activities will occur late in the rainy season, but in case of a flood due to snow melt, such as what happened in Portland last January, should an inspection or minor maintenance have performed on the units mid-season?

13. When a facility requires media replacement, does it need to be ordered specifically for that installation or can the agency order in bulk and store the media for subsequent uses? Does the media have a shelf life before it begins to degrade?

\section{INITIAL \& ANNUAL MAINTENANCE COSTS}

14. Provide information on typical cost per model unit, installed.

15. Based on the recommended major and minor maintenance / inspection. Please provide detailed information about the cost of replacing or cleaning cartridges or other unit media.

\section{DISCUSSION:}

16. Provide input on the City of Seattle's proposal to move to a solids-loading basis for system sizing and maintenance. It's our understanding Seattle's proposal stems from the results of a Seattle field evaluation of the performance of a group of StormFilter installations. 